\title{
Green manure effect on the ability of native and inoculated soil bacteria to mobilize zinc for wheat uptake (Triticum aestivum L.)
}

\author{
Benjamin Costerousse (D) Joel Quattrini • \\ Roman Grüter · Emmanuel Frossard • \\ Cécile Thonar
}

Received: 14 April 2021 / Accepted: 1 July 2021 / Published online: 30 July 2021

(C) The Author(s) 2021

\begin{abstract}
Purpose Green manuring can increase the plant available fraction of zinc $(\mathrm{Zn})$ in soil, making it a potential approach to increase wheat $\mathrm{Zn}$ concentrations and fight human $\mathrm{Zn}$ deficiency. We tested whether green manure increases the ability of both the native soil bacteria and inoculated $\mathrm{Zn}$ solubilizing bacteria (ZSB) to mobilize $\mathrm{Zn}$.

Methods Wheat was grown in a pot experiment with the following three factors (with or without); (i) clover addition; (ii) soil x-ray irradiation (i.e. elimination of the whole soil biota followed by reinoculation with the native soil bacteria); and (iii) ZSB inoculation. The incorporation of clover in both
\end{abstract}

Responsible Editor: Katharina Maria Keiblinger.

Supplementary Information The online version contains supplementary material available at https://doi. org/10.1007/s11104-021-05078-6.

B. Costerousse $(\bowtie) \cdot$ J. Quattrini $\cdot$ E. Frossard Group of Plant Nutrition, Institute of Agricultural Sciences (IAS), ETH Zurich, Lindau, Switzerland

e-mail: benjamin.costerousse@cogreen.eu

R. Grüter

Institute of Terrestrial Ecosystems, ETH Zurich, Zürich, Switzerland

Present Address:

R. Grüter

Institute of Natural Resource Sciences, Zurich University

of Applied Sciences (ZHAW), Wädenswil, Switzerland the irradiated and the ZSB treatments allowed us to test green manure effects on the mobilization of $\mathrm{Zn}$ by indigenous soil bacteria as well as by inoculated strains.

Results Inoculation with ZSB did neither increase soil $\mathrm{Zn}$ availability nor wheat $\mathrm{Zn}$ uptake. The highest soil $\mathrm{Zn}$ availabilities were found when clover was incorporated, particularly in the irradiated soils (containing only soil bacteria). This was partly associated with the stimulation of bacterial activity during the decomposition of the incorporated green manure.

Conclusion The results support that the activity of soil bacteria is intimately involved in the mobilization of $\mathrm{Zn}$ following the incorporation of green manure.

Keywords Green manure $\cdot$ Legume $\cdot$ Soil bacteria . Zinc mobilization $\cdot$ Zinc solubilizing bacteria

\author{
C. Thonar \\ Department of Soil Sciences, Research Institute of Organic \\ Agriculture (FiBL), Frick, Switzerland \\ Present Address: \\ C. Thonar \\ Plant Genetics and Rhizosphere Processes, TERRA \\ Teaching and Research Center, Gembloux Agro-Bio Tech, \\ University of Liège, Gembloux, Belgium
}




\begin{tabular}{|c|c|}
\hline Abbreviations & \\
\hline ZSB & Zinc solubilizing bacteria \\
\hline $\mathrm{AM}$ & Arbuscular mycorrhizae \\
\hline HIGH Zn soil & $\begin{array}{l}\text { Soil with sufficient plant } \mathrm{Zn} \\
\text { availabity }\end{array}$ \\
\hline LOW Zn soil & Soil with low plant $\mathrm{Zn}$ availabity \\
\hline DGT & $\begin{array}{l}\text { Diffusive gradients in thin films } \\
\text { method }\end{array}$ \\
\hline NO GM & $\begin{array}{l}\text { Treatments without green manure } \\
\text { addition }\end{array}$ \\
\hline$+\mathrm{GM}$ & $\begin{array}{l}\text { Treatments with green manure } \\
\text { addition }\end{array}$ \\
\hline NO IRR & Treatments with non-irradiated soil \\
\hline X-RAY IRR & Treatments with $\mathrm{x}$-ray irradiated soil \\
\hline NO ZSB & Treatments without ZSB inoculation \\
\hline$+\mathrm{ZSB}$ & Treatment with ZSB inoculation \\
\hline DTPA & Diethylene triamine penta-acetic acid \\
\hline $\mathrm{cfu}$ & Colony forming unit \\
\hline ANOVA & Analyses of variance \\
\hline
\end{tabular}

\section{Introduction}

Zinc $(\mathrm{Zn})$ is an essential micronutrient as it contributes to protein structure and function in all living organisms (Broadley et al. 2007; Holt et al. 2012). Soil available $\mathrm{Zn}$ refers to the fraction present in soluble forms in the soil solution that can be directly absorbed by plant roots (Nolan et al. 2003). About $50 \%$ of the soils used for cereal cultivation are low in plant available Zn (Graham and Welch 1996). When the availability of $\mathrm{Zn}$ in soil is not sufficient to cover crop physiological requirements, cereal yield quantity and quality (i.e. Zn concentration in edible parts) are reduced (Alloway 2009; Frossard et al. 2000). The production of low-Zn cereal grains contributes largely to human $\mathrm{Zn}$ deficiency in low income countries, because, in such areas, diets are often based on cereal meals. Soil factors associated with low soil $\mathrm{Zn}$ availability include high $\mathrm{pH}$, high clay, high calcium carbonate content and low total $\mathrm{Zn}$ content (Alloway 2009).

To fight $\mathrm{Zn}$ deficiency in humans, biofortification strategies aim at increasing the density of $\mathrm{Zn}$ in the edible parts of crops. These range from the application of inorganic $\mathrm{Zn}$ fertilizer to the development of new cereal cultivars more efficient in taking up $\mathrm{Zn}$ and transferring it to the grains (Cakmak 2008). Cadmium (Cd) is chemically similar to $\mathrm{Zn}$ and has numerous adverse effects on human health when ingested chronically (Godt et al. 2006). Competition (Hart et al. 2002), but also synergy (Nan et al. 2002; Sarwar et al. 2014) have been reported between the uptake of $\mathrm{Zn}$ and $\mathrm{Cd}$ by wheat and thus, both metals should be considered while studying $\mathrm{Zn}$ biofortification.

An alternative (or complementary) strategy is to act on soil physicochemical (e.g. pH, organic matter content) and biological (e.g. microbial activity) parameters governing the availability of $\mathrm{Zn}$ in soil. For this, green manure (i.e. any plant material incorporated into the soil while green or soon after maturity primarily to improve soil fertility) has the advantage not only to release soluble $\mathrm{Zn}$ from decomposing biomass, but also and above all to promote the mobilization of $\mathrm{Zn}$ in soil (Aghili et al. 2014; Siddique et al. 2014). $\mathrm{Zn}$ mobilization in soil is defined as the transfer of $\mathrm{Zn}$ bound to soil particles (e.g. organic matter, iron $(\mathrm{Fe})$ oxides) to more soluble $\mathrm{Zn}$ species in the soil solution (either as free $\mathrm{Zn}^{2+}$ or as $\mathrm{Zn}^{2+}$ bound to soluble organic compounds).

In a pot experiment performed with an Iranian soil low in plant available Zn, Aghili et al. (2014) observed an increase in wheat grain $\mathrm{Zn}$ concentrations from 20 to $31 \mathrm{mg} \mathrm{Zn} \mathrm{kg}{ }^{-1}$ when sunflower green manure was incorporated compared to the non-amended control. Increased wheat $\mathrm{Zn}$ uptake upon green manure incorporation has been reported in a few other pot and field experiments (Grüter et al. 2017a; Habiby et al. 2014; Soltani et al. 2014). In these studies, increased $\mathrm{Zn}$ phytoavailability following the addition of green manure was mainly thought to be associated with (i) the mobilization of $\mathrm{Zn}$ through the release of small organic ligands (e.g. organic and amino acids) from decomposing green manure which can form soluble complexes with soil bound $\mathrm{Zn}$ (Gramlich et al. 2013); (ii) the addition of nitrogen $(\mathrm{N})$ through biological fixation by Fabaceae that can stimulate the plant synthesis of $\mathrm{Zn}$ membrane transporters and organic ligands (e.g. amino acids, nicotianamine) involved in $\mathrm{Zn}$ uptake, transport and storage within plants (Palmer and Guerinot 2009) and (iii) the stimulation of soil microbial activity resulting in the mobilization of $\mathrm{Zn}$, e.g. through the mineralization of soil organic matter and the release of organically bound $\mathrm{Zn}$ (Bingeman et al. 1953).

In addition to decomposing exogenous and soil organic matter, soil fungi and bacteria are involved 
in a variety of soil chemical reactions controlling $\mathrm{Zn}$ phytoavailability. Furthermore, arbuscular mycorrhizae (AM) are known for their role in facilitating plant phosphorus $(\mathrm{P})$ and $\mathrm{Zn}$ acquisition by enhancing root soil exploitation (Jansa et al. 2003; Kothari et al. 1991; Ortas 2012; Watts-Williams et al. 2013). On the other hand, ericoid and ectomycorrhiza are examples of soil fungi that, by the production of various metabolites such as protons and organic acids (e.g. malate, citrate), can mobilize $\mathrm{Zn}$ bound to soil particles and soil organic matter and increase the bioavailability of $\mathrm{Zn}$ in the rhizosphere (Fomina et al. 2005; Martino et al. 2003). Similar Zn mobilization mechanisms have been highlighted for specific heterotrophic bacterial strains, often referred to as Zinc Solubilizing Bacteria (ZSB) (Costerousse et al. 2018; Saravanan et al. 2007; Sunithakumari et al. 2016). Several soil bacterial isolates have been shown to obtain $\mathrm{Zn}$ from their environment by producing and taking up Zn-chelating siderophores (Bobrov et al. 2014; Leach et al. 2007). Such compounds are also suspected to facilitate the mobilization of $\mathrm{Zn}$ in the rhizosphere (Hafeez et al. 2013). Another microbial process controlling the availability of $\mathrm{Zn}$ corresponds to the release of ammonium $\left(\mathrm{NH}_{4}^{+}\right)$(e.g. during the decomposition of organic matter) which may exchange with soil bound $\mathrm{Zn}$ or promote the release of protons (i.e. through nitrification). Carbon dioxide $\left(\mathrm{CO}_{2}\right)$ released from microbial respiration may also contribute to $\mathrm{Zn}$ mobilization through its dissolution in water and the following release of protons from the dissociation of carbonic acid $\left(\mathrm{H}_{2} \mathrm{CO}_{3}\right)$.

In a pot study performed with a Cd-contaminated soil, Muehe et al. (2015) reported that a strong alteration of native soil microbial communities (i.e. soil irradiation with $\gamma$-rays leading to a decrease in diversity) did not affect soil $\mathrm{HCl}$-extractable $\mathrm{Zn}$ and $\mathrm{Cd}$ nor Arabidopsis halleri growth but reduced plant $\mathrm{Zn}$ and Cd uptake. Some other pot (Khande et al. 2017; Singh et al. 2017) and field studies (Abaid-Ullah et al. 2015; Sharma et al. 2012) found that inoculation with ZSB increased crop Zn uptake as a result of increased $\mathrm{Zn}$ phytoavailability. These experiments suggest that soil microorganisms can have a positive impact on the availability of metals in soil. Zn mobilization by the native soil bacteria and/or inoculated ZSB is likely stimulated by nutrients and energy supplied by decomposing green manure. However, this remains to be tested.

To achieve this, we performed a factorial pot experiment including two green manure treatments, with or without the addition of clover (Trifolium alexandrinum L.). After green manure incorporation, half of the experimental soil was $\mathrm{x}$-ray irradiated, which eliminated soil biota (including soil fungi), and reinoculated exclusively with native soil bacteria. Additionally, a mix of six ZSB (their potential to increase $\mathrm{Zn}$ availability under in vitro conditions is described in Costerousse et al. (2018)), was inoculated to half of the pots. Spring wheat (Triticum aestivum L.) was grown to maturity in all these treatments and the experiment was conducted in two soils, one with sufficient (HIGH Zn soil) and one with low Zn availability (LOW Zn soil). The diffusive gradients in thin films (DGT) method were used as a sensitive proxy to monitor changes in plant available $\mathrm{Zn}$ throughout the pot experiment (Grüter et al. 2017a; Tandy et al. 2011). Treatment effects on Cd availability in soil and uptake by wheat was also monitored. We expected that $\mathrm{Zn}$ availability (and wheat $\mathrm{Zn}$ uptake) would be greater in the soils treated with clover, especially in the treatments simultaneously inoculated with ZSB. In other words, we hypothesized that the incorporation of clover would amplify $\mathrm{Zn}$ mobilization by native soil bacteria and the inoculated ZSB.

\section{Materials and methods}

Design and timeline of the pot experiment

A cross-factorial pot experiment was performed in which spring wheat (Triticum aestivum L., cv. Fiorina) was cultivated in two soils: one with sufficient (HIGH $\mathrm{Zn}$ soil) and one with non-sufficient plant available $\mathrm{Zn}$ (LOW $\mathrm{Zn}$ soil). The design of the pot experiment consisted of three factors with two levels each; (i) green manure addition (no green manure (NO GM), Trifolium alexandrinum (also designated as clover) (+GM)); (ii) soil x-ray irradiation (nonirradiated (NO IRR), X-ray irradiated (X-RAY IRR)); and (iii) ZSB inoculation ((NO ZSB), inoculated $(+\mathrm{ZSB}))$. Destructive soil and plant sampling was done at two time points, i.e. wheat flowering (i.e. 60 days after wheat planting for HIGH Zn and 66 days 
for LOW Zn) and wheat maturity (i.e. 123 days after wheat planting). For each time point, four experimental replicates were prepared. This resulted in 128 pots $(4 * 2(\mathrm{GM}) * 2(\mathrm{IRR}) * 2(\mathrm{ZSB}) * 2$ (SOIL) $* 2$ (Sampl ing points)), all arranged in a completely randomized design on the glasshouse bench with rearrangement of the pots every second week.

Clover was grown and incorporated in half of the HIGH $\mathrm{Zn}$ and the LOW $\mathrm{Zn}$ soils before wheat was planted to all the treatments. There were therefore two successive plant cultures on the same soils in the + GM treatments, whereas only wheat was grown in the NO GM treatments. After green manure growth and incorporation (but before wheat planting), half of the experiment soils (with and without green manure) were X-ray irradiated and re-inoculated with the native soil bacteria. ZSB were inoculated to the wheat seedlings and to the soil at wheat planting and only to the soil at wheat flowering.

Origins, characteristics and initial fertilization of the two soils

The soil with sufficient $\mathrm{Zn}$ plant availability (HIGH $\mathrm{Zn}$ soil) was sampled from the long-term field trial "Zurich Organic Fertilizer Experiment" (ZOFE) conducted at the research institute for sustainability sciences (ISS) (Agroscope, Zurich Reckenholz, Switzerland) (Oberholzer et al. 2014). This old field experiment, established in 1949, aims at comparing the effects of different organic and inorganic fertilization regimes on crop yield and soil chemical and biological properties. The HIGH Zn soil was sampled from the farmyard manure treatment (FYM) mainly because it had the highest diethylene triamine pentaacetic acid (DTPA) extractable $\mathrm{Zn}\left(4.22 \mathrm{mg} \mathrm{kg}^{-1}\right)$ compared to other treatments of the ZOFE trial. The soil with non-sufficient plant $\mathrm{Zn}$ availability (LOW Zn soil) was imported from Turkey, Central Anatolia. The LOW Zn soil had DTPA extractable Zn concentrations below $0.5 \mathrm{mg} \mathrm{kg}^{-1}\left(0.23 \mathrm{mg} \mathrm{kg}^{-1}\right)$, and can therefore be considered as low in plant available $\mathrm{Zn}$ (Cakmak et al. 1996).

Initial soil characteristics are described in Table 1. The HIGH Zn soil was a carbonate free and acidic (pH 5.5) while the LOW $\mathrm{Zn}$ soil contained carbonate and was slightly alkaline ( $\mathrm{pH}$ 7.3). The LOW Zn soil had a higher clay content and cation exchange capacity compared to the HIGH $\mathrm{Zn}$ soil. Total $\mathrm{Cd}, \mathrm{N}$ and
$\mathrm{Zn}$ contents were higher in the HIGH Zn soil as compared to the LOW Zn. Likewise, DTPA extractable trace elements, Olsen $\mathrm{P}$, microbial $\mathrm{C}$ and $\mathrm{N}$ biomasses and organic $\mathrm{C}$ were higher in the HIGH $\mathrm{Zn}$ than in the LOW Zn soil.

All essential macro- and micronutrients (except $\mathrm{Zn}$ ) were added to the two soils at green manure sowing and $\mathrm{N}$ was added again at wheat planting, wheat tillering and wheat flowering resulting in total in $100 \mathrm{mg} \mathrm{N}$ added per kg-1 soil (Table 2).

Green manure growth and incorporation

The green manure used in this study was the Fabaceae Trifolium alexandrinum L. cv. Elite II. Green manure seeds were purchased from Fenaco (UFA Samen, Winthertur, Switzerland). For each soil, four boxes $(36 \mathrm{~cm} \mathrm{~W} * 35 \mathrm{~cm} \mathrm{D} * 15 \mathrm{~cm} \mathrm{H})$ were filled with $14 \mathrm{~kg}$ of soil (dry weight equivalent). The initial fertilization was then applied to the eight boxes (Table 2), and soils were mixed carefully to ensure homogenous distribution of the nutrients. Half of the boxes, labelled as + GM, were used for growing T. alexandrinum while the other half, labelled as NO GM, were used as control treatment with no green manure amendment. Clover was sown directly on the soil surface at a rate of $0.08 \mathrm{~g}$ per kg-1 soil (i.e. equivalent seeding density of $90 \mathrm{~kg} \mathrm{ha}^{-1}$ ). Soil moisture in the boxes was maintained around $60 \%$ water holding capacity by adding water frequently. All boxes (with and without green manure) were transferred to the glasshouse with climatic conditions set to a photoperiod of $16 \mathrm{~h}$ with a light intensity of $50 \mathrm{kLux}$, a relative humidity of $65-70 \%$ and day/night temperature of $22{ }^{\circ} \mathrm{C} / 16^{\circ} \mathrm{C}$.

Two weeks after green manure sowing, the LOW Zn soil was inoculated with Rhizobium leguminosarum (strain reference: DSMZ No. 30139) to ensure effective nodulation of the clover. This rhizobium strain was obtained from the German Collection of Microorganisms and Cell Cultures (https:// www.dsmz.de/). For this purpose, $R$. leguminosarum was incubated and multiplied for 4 days on a rotary shaker at $28{ }^{\circ} \mathrm{C}$ in Yeast Extract Mannitol (YEM) broth prepared with yeast extract $1 \mathrm{~g} \mathrm{l}^{-1}$, mannitol $10 \mathrm{~g} \mathrm{l}^{-1}, \mathrm{~K}_{2} \mathrm{HPO}_{4} 0.5 \mathrm{~g} \mathrm{l}^{-1}, \mathrm{MgSO}_{4} 0.2 \mathrm{~g} \mathrm{l}^{-1}$ and Nacl $0.1 \mathrm{~g} \mathrm{l}^{-1}$. To inoculate LOW Zn, $20 \mathrm{ml}$ of this $R$. leguminosarum culture was dispensed per $\mathrm{kg}^{-1}$ dry soil. R. leguminosarum was also inoculated in LOW $\mathrm{Zn}$ where no green manure was grown. The HIGH Zn 
Table 1 Physicochemical and biological properties of the two soils used in this study

\begin{tabular}{|c|c|c|}
\hline Parameter $^{\mathrm{a}}$ & HIGH Zn & LOW Zn \\
\hline $\mathrm{pH}\left(\mathrm{CaCl}_{2}\right)$ & 5.47 & 7.34 \\
\hline Clay $\left(\mathrm{g} \mathrm{kg}^{-1}\right)$ & 139 & 233 \\
\hline Texture $^{\mathrm{b}}$ & sandy loam & sandy clay loam \\
\hline Cation exchange capacity $\left(\mathrm{cmol}(+) \mathrm{kg}^{-1}\right)$ & 5.66 & 34.76 \\
\hline Maximum water holding capacity $\left(\mathrm{H}_{2} \mathrm{O}(\mathrm{ml})\right.$ per $\mathrm{kg}$ soil $\left.\mathrm{DW}^{-1}\right)$ & 300 & 494 \\
\hline Total inorganic $\mathrm{C}\left(\mathrm{g} \mathrm{kg}^{-1}\right)$ & $<\operatorname{LOD}^{\mathrm{c}}$ & 14.90 \\
\hline Total organic $\mathrm{C}\left(\mathrm{g} \mathrm{kg}^{-1}\right)$ & 10.93 & 5.10 \\
\hline Total Cd $\left(\mu \mathrm{g} \mathrm{kg}^{-1}\right)$ & 352.7 & 67.8 \\
\hline Total N $\left(\mathrm{g} \mathrm{kg}^{-1}\right)$ & 1.04 & 0.38 \\
\hline Total $\mathrm{Zn}\left(\mathrm{mg} \mathrm{kg}^{-1}\right)$ & 76.6 & 26.6 \\
\hline DGT extractable Cd $\left(\mu \mathrm{g} \mathrm{l}^{-1}\right)$ & 0.427 & $<\mathrm{LOD}^{\mathrm{c}}$ \\
\hline DGT extractable $\mathrm{Zn}\left(\mu \mathrm{g} 1^{-1}\right)$ & 15.6 & $<\operatorname{LOD}^{\mathrm{c}}$ \\
\hline DTPA extractable $\mathrm{Cd}\left(\mu \mathrm{g} \mathrm{kg}^{-1}\right)$ & 125.7 & 10.0 \\
\hline DTPA extractable $\mathrm{Zn}\left(\mathrm{mg} \mathrm{kg}^{-1}\right)$ & 4.22 & $0.23^{\mathrm{d}}$ \\
\hline Olsen $\mathrm{P}\left(\mathrm{mg} \mathrm{kg}^{-1}\right)$ & 36.27 & 2.12 \\
\hline Basal soil respiration $\left(\mathrm{mg} \mathrm{CO}_{2}-\mathrm{C} \mathrm{kg}^{-1} \mathrm{~h}^{-1}\right)$ & 0.231 & 0.274 \\
\hline Microbial C $\left(\mathrm{mg} \mathrm{C} \mathrm{kg}^{-1}\right)$ & 83.3 & 26.1 \\
\hline Microbial $\mathrm{N}\left(\mathrm{mg} \mathrm{N} \mathrm{kg}^{-1}\right)$ & 15.7 & 3.09 \\
\hline
\end{tabular}

Soil analyses were performed before green manure sowing as an initial soil characterization

${ }^{a}$ Apart from total soil N, DGT extractable $\mathrm{Zn}$ and $\mathrm{Cd}$, basal soil respiration and microbial $\mathrm{C}$ and $\mathrm{N}$ biomasses, the rest of the soil parameters given in this table was obtained from Grüter et al. (2017b)

b IUSS Working Group WRB (2014)

${ }^{\mathrm{c}}$ Below limit of detection (<LOD)

${ }^{\mathrm{d}}$ For LOW Zn, the DTPA extractable $\mathrm{Zn}$ was below $0.5 \mathrm{mg} \mathrm{kg}^{-1}$, commonly considered as the Zn deficiency threshold (Cakmak et al. 1996)

Table 2 Nutrients added before green manure sowing and $\mathrm{N}$ application throughout wheat growth

\begin{tabular}{|c|c|c|c|}
\hline Time of application & Element & Compound & Fertilization $\left(\mathrm{mg} \mathrm{kg} \mathrm{soil}{ }^{-1}\right)$ \\
\hline \multicolumn{4}{|c|}{ Before green manure sowing } \\
\hline & $\mathrm{N}$ & $\mathrm{Mg}\left(\mathrm{NO}_{3}\right)_{2} \cdot \mathrm{KNO}_{3} \cdot \mathrm{Cu}\left(\mathrm{NO}_{3}\right)_{2}$ & 25 \\
\hline & $\mathrm{P}$ & $\mathrm{KH}_{2} \mathrm{PO}_{4}$ & 60 \\
\hline & $\mathrm{K}$ & $\mathrm{KH}_{2} \mathrm{PO}_{4} \cdot \mathrm{K}_{2} \mathrm{SO}_{4} \cdot \mathrm{KNO}_{3}$ & 150 \\
\hline & $\mathrm{S}$ & $\mathrm{K}_{2} \mathrm{SO}_{4} \cdot \mathrm{MnSO}_{4}$ & 25 \\
\hline & $\mathrm{Fe}$ & FeNaEDTA & 10 \\
\hline & $\mathrm{B}$ & $\mathrm{H}_{3} \mathrm{BO}_{3}$ & 0.691 \\
\hline & $\mathrm{Mn}$ & $\mathrm{MnSO}_{4}$ & 0.703 \\
\hline & $\mathrm{Mg}$ & $\mathrm{Mg}\left(\mathrm{NO}_{3}\right)_{2}$ & 17.2 \\
\hline & $\mathrm{Cu}$ & $\mathrm{Cu}\left(\mathrm{NO}_{3}\right)_{2}$ & 0.081 \\
\hline & Mo & $\mathrm{Na}_{2} \mathrm{MoO}_{4}$ & 0.061 \\
\hline \multicolumn{4}{|c|}{ At wheat planting, tillering and flowering (applied three times) } \\
\hline & $\mathrm{N}$ & $\mathrm{NH}_{4} \mathrm{NO}_{3}$ & 25 at each time point \\
\hline
\end{tabular}


soil was not inoculated with this rhizobium as preliminary tests highlighted infectious potential of this soil. Nodules were found on clover roots in both soils after 6 weeks of growth.

At this time, the green manure shoots were cut $1 \mathrm{~cm}$ above soil surface, pooled separately for each soil to a single green manure sample, dried at $60{ }^{\circ} \mathrm{C}$, weighed for biomass estimation and milled homogeneously. From each of the two green manure samples, ca. $3 \mathrm{~g}$ of dry shoot matter were taken for total $\mathrm{C}, \mathrm{N}, \mathrm{Zn}$ and Cd element analyses (cf. "Plant analyses"). Soils were left for 3 weeks under the same conditions in the glasshouse to allow for green manure root decomposition. Only then, milled green manure shoots were transferred to their respective + GM box and soils were mixed again homogeneously. After an additional week of equilibration in the glasshouse, soils were transferred to $4{ }^{\circ} \mathrm{C}$ until further use.

Soil x-ray irradiation and re-inoculation with native bacteria

The goal of soil x-ray irradiation and re-inoculation was to obtain soils containing only bacterial communities. In this context, half the volume of NO GM and $+\mathrm{GM}$ soils (i.e. containing green manure residues) were transported to Synergyhealth (Däniken, Switzerland, http://www.synergyhealthplc.com/us) where they were $\mathrm{x}$-ray irradiated with a dose range of 25 to $75 \mathrm{kGy}$. Such levels of irradiation have been reported to kill soil bacteria, fungi and invertebrates (McNamara et al. 2003). Soil sterility was checked after irradiation by inoculating Nutrient Agar (NA) with tenfold serial dilutions according to Trevors (1996) (data not shown). In order to re-introduce native soil bacterial communities in $\mathrm{x}$-ray irradiated soils, $6.25 \mathrm{~mL}$ of filtered soil suspensions (25\% (w:v) in $0.3 \mathrm{~g} \mathrm{~L}^{-1} \mathrm{NaCl}$ ) were added per $\mathrm{kg}^{-1}$ dry soil (the same volume of sterile $\mathrm{NaCl} 0.3 \mathrm{~g} \mathrm{~L}^{-1}$ was added to each NO-IRR treatment). This was done following the procedure described by Aghili et al. (2014), except that we used two additional filtration steps, one through Whatman No. 42 filter paper (i.e. $2.5 \mu \mathrm{m}$ pore size) in order to exclude fungi mycelia and spores, and a final filtration step through $0.22 \mu \mathrm{m}$ pore size membranes to concentrate tenfold the obtained soil filtrates so as to reduce their volume. The 3-step filtration procedure used to prepare each soil filtrate (referred later as "bacterial wash") is described in details in the supplementary material (Sect. 1). Each bacterial wash was prepared from the corresponding NO IRR soil.

\section{ZSB inoculation}

Half of the pots were inoculated with a mix consortium of ZSB including three strains of Pseudomonas (P. chlororaphis, P. moraviensis, P. syringae; accession numbers from 16S rRNA gene sequences blasted against the NCBI nr database: FJ652611.1, HG000013.1, AY574913.1), two strains of Plantibacter flavus (both HE716918.1) and one strain of Streptomyces narbonensis (KU324447). Two of the inoculated strains ( $S$. narbonensis and P. moraviensis) were isolated from the HIGH $\mathrm{Zn}$ soil itself, and the four others from a soil with very similar chemical properties as reported in Costerousse et al. (2018). In the same study, the six inoculated ZSB were selected out of $115 \mathrm{Zn}$ solubilizing isolates based on their abilities to produce organic acids, release siderophores and dissolve scarcely soluble $\mathrm{Zn}$ salts ( $\mathrm{Zn}$ oxide and $\mathrm{Zn}$ carbonate) in plate and broth assays. To multiply ZSB for wheat seedlings and soil inoculation, ZSB were grown separately overnight in Nutrient Broth (NB) (peptone $5 \mathrm{~g} \mathrm{l}^{-1}$ (BD Difco, Allschwil, Switzerland), meat extract $3 \mathrm{~g} \mathrm{l}^{-1}$ (Sigma-Aldrich, Buchs, Switzerland)) with shaking at $28{ }^{\circ} \mathrm{C}$. To quantify viable bacterial cells in NB, relation between optical density (OD) at $600 \mathrm{~nm}$ with the number of Colony Forming Units (CFU) per $\mathrm{mL}$ was used.

In the + ZSB treatments, the 6 strains were inoculated to the wheat seedlings (i.e. prior to planting) and twice to the soil (i.e. at wheat planting and flowering). This was done to promote survival and persistence of the inoculated strains in soil and at the interface of the wheat roots throughout the pot experiment. Indeed, previous soil inoculation studies with phosphorus solubilizing bacteria have shown that density of inoculated strains may decrease within one month after inoculation (Meyer et al. 2017a; Mosimann et al. 2017).

For seedling inoculation, wheat seeds were germinated (cf. next section of the materials and methods, "Pot experiment") and four days old seedlings were dipped for $2 \mathrm{~h}$ in a 2 -L bacterial suspension

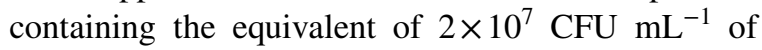
each ZSB. For soil inoculation, NB aliquots containing $8 \times 10^{9} \mathrm{CFU}$ from each ZSB were pooled and 
centrifuged at $3000 \mathrm{~g}$ for $10 \mathrm{~min}$. Using $\mathrm{NaCl} 0.3 \mathrm{~g}$ $\mathrm{L}^{-1}$, bacterial cells were washed twice and cell con-

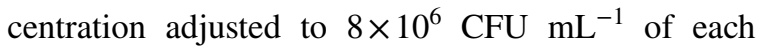
ZSB. At wheat planting and flowering, $12.5 \mathrm{~mL}$ from this mixed ZSB suspension was added per $\mathrm{kg}$ of dry soil and hence, the equivalent of $10^{5} \mathrm{CFU}$ of each ZSB was added per $\mathrm{g}$ of soil at both time points (or $7.5 \times 10^{7}$ CFU per pot $^{-1}$ ).

\section{Pot experiment}

The pots were previously washed with hot water, sprayed with ethanol $70 \%$ and air dried. The following solutions were applied and mixed to the soils prior to potting (i.e. per $\mathrm{kg}$ dry weight); (i) $12.5 \mathrm{~mL}$ of initial $\mathrm{N}$ fertilization solution (containing $25 \mathrm{mg}$ of $\mathrm{N}$ in the form of $\mathrm{NH}_{4} \mathrm{NO}_{3}$; Table 2), (ii) $6.25 \mathrm{~mL}$ of filtered soil suspension (bacterial wash) in X-RAY IRR treatments and (iii) $12.5 \mathrm{~mL}$ of mixed ZSB suspension in + ZSB treatments (the same volumes of sterile $\mathrm{NaCl} 0.3 \mathrm{~g} \mathrm{~L}^{-1}$ was added to NO IRR and NO ZSB pots). After mixing the soils thoroughly, samples were taken for soil analyses at wheat planting and $750 \mathrm{~g}$ of soil (dry weight equivalent) were placed into each pot.

When setting up the pot experiment, all wheat seeds (Triticum aestivum L., cv. Fiorina) were surface sterilized with $10 \% \mathrm{H}_{2} \mathrm{O}_{2}$ for $30 \mathrm{~min}$ and $0.3 \%$ previcur fungicide (propamocarb and fosetyl, Bayer) for $20 \mathrm{~min}$. After rinsing with autoclaved nanopure water, the seeds were placed on autoclaved sand for 4 days during which germination and primary growth of the seedlings occurred. Half of the seedlings were inoculated with ZSB. The pots were transferred to a glasshouse bench and two wheat seedlings were planted per pot (thinned to only one plant per pot one week later). Climatic conditions were set to a photoperiod of $14 \mathrm{~h}$ (light intensity of $12 \mathrm{kLux}$ ), a relative humidity of $40-45 \%$ and day/night temperature of $20{ }^{\circ} \mathrm{C} / 14{ }^{\circ} \mathrm{C}$. Soil moisture in the pots was raised on a balance to ca. $60 \%$ water holding capacity by watering every second day.

\section{Soil analyses}

Soil analyses were performed at three time points: before green manure sowing (i.e. for the initial soil characterization; Table 1), at wheat planting (i.e. on soil samples taken after the addition of $\mathrm{N}$ and the bacterial wash (in X-RAY IRR treatments) or the $\mathrm{NaCl}$ solution (in NO IRR treatments)) and at wheat flowering. At this time point, half of the pots were sampled destructively for soil and wheat shoot analyses. The remaining half of the pots were maintained until wheat maturity where no soil but only wheat roots, shoots and grains were sampled and analyzed. No soil analyses were performed at wheat planting on the + ZSB soil treatments as ZSB consortium had just been inoculated and had had no time to take action.

Table 3 summarizes the various soil analyses performed at each time point and how the soil samples were prepared for analysis. Clay content, soil texture, cation exchange capacity, maximum water holding capacity, soil organic and inorganic $\mathrm{C}$ content, total element concentrations, DTPA extractable $\mathrm{Zn}$ and $\mathrm{Cd}$ and Olsen $\mathrm{P}$ data were obtained from Grüter et al. (2017b), where the analytical methods can also be found. The methods used for the remaining soil analyses (soil pH, total soil N, DGT extractable $\mathrm{Zn}$ and $\mathrm{Cd}$, soil respiration, microbial $\mathrm{C}$ and $\mathrm{N}$ contents and soil mineral $\mathrm{N}$ concentrations) can be found in the supplementary material (Sect. 2).

\section{Plant analyses}

Milled and oven dried green manure shoot samples $\left(60{ }^{\circ} \mathrm{C}\right)$ were taken before it was incorporated to the corresponding soil.

At wheat flowering, half of the pots were removed from the glasshouse for wheat root and shoots sampling. We used the root staining procedure described by Phillips and Hayman (1970) to look for mycorrhizal structures and compare root mycorrhizal colonization among the treatments at wheat flowering. Wheat shoots were cut $1 \mathrm{~cm}$ above the ground, dried for 5 days at $40{ }^{\circ} \mathrm{C}$, weighed and milled.

At wheat maturity, the plants were harvested and processed following the same procedure. The wheat shoots (i.e. including chaff) were separated from the wheat grains. At wheat maturity only, the roots were washed with tap water, and dried at $40{ }^{\circ} \mathrm{C}$ for wheat root biomass determination. Number of ears, grains per ear and grains per pots were also reported at wheat maturity.

Plant $\mathrm{Zn}$ and $\mathrm{Cd}$ concentrations were measured by digesting $200 \mathrm{mg}$ of dried plant material in $2 \mathrm{~mL}$ $11 \mathrm{M} \mathrm{HNO}_{3}$ for $30 \mathrm{~min}$ at ca. $250{ }^{\circ} \mathrm{C}$ and a pressure of $40 \mathrm{bar}$ in the high pressure single reaction change 
Table 3 List of soil analyses performed at the different time points

\begin{tabular}{|c|c|c|c|c|}
\hline \multirow[b]{2}{*}{ Parameters } & \multicolumn{3}{|l|}{ Time point } & \multirow{2}{*}{$\begin{array}{l}\text { Soil } \\
\text { prepa- } \\
\text { ration }\end{array}$} \\
\hline & $\begin{array}{l}\text { Before green manure } \\
\text { sowing }\end{array}$ & Wheat planting & Wheat flowering & \\
\hline $\mathrm{pH}$ & $\mathrm{x}$ & $\mathrm{x}$ & $\mathrm{x}$ & $\mathrm{b}$ \\
\hline Clay & $\mathrm{x}$ & & & $\mathrm{b}$ \\
\hline Texture & $\mathrm{x}$ & & & $\mathrm{b}$ \\
\hline Cation exchange capacity & $\mathrm{x}$ & & & a \\
\hline Maximum water holding capacity & $\mathrm{x}$ & & & a \\
\hline Soil organic and inorganic $\mathrm{C}$ content & $\mathrm{x}$ & & & $\mathrm{b}$ \\
\hline Total element concentrations & $\mathrm{x}$ & & & $\mathrm{b}$ \\
\hline Total soil N & $\mathrm{x}$ & $\mathrm{x}$ & $\mathrm{x}$ & $\mathrm{b}$ \\
\hline DGT extractable $\mathrm{Zn}$ and Cd & $\mathrm{x}$ & $\mathrm{x}$ & $\mathrm{x}$ & a \\
\hline DTPA extractable $\mathrm{Zn}$ and $\mathrm{Cd}$ & $\mathrm{x}$ & & & $\mathrm{b}$ \\
\hline Olsen P & $\mathrm{x}$ & & & $\mathrm{b}$ \\
\hline Soil respiration & $\mathrm{x}$ & & $\mathrm{x}$ & a \\
\hline Microbial C & $\mathrm{x}$ & & $\mathrm{x}$ & a \\
\hline Microbial N & $\mathrm{x}$ & & & a \\
\hline Soil mineral $\mathrm{N}\left(\mathrm{NO}_{3}^{-}\right.$and $\left.\mathrm{NH}_{4}^{+}\right)$ & & $\mathrm{X}$ & $\mathrm{X}$ & $\mathrm{a}$ \\
\hline
\end{tabular}

${ }^{a}$ parameters measured on moist soil. Fresh soil samples were always kept at 4 degrees between their collection and their analyses

${ }^{b}$ analyses performed on oven dried soil $\left(40^{\circ} \mathrm{C}\right.$ for $48 \mathrm{~h}$ ), sieved $2 \mathrm{~mm}$ and ground with a vibratory disc mill. For texture analysis, the soil was not ground

microwave system (turboWave, MWS microwave systems, Leutkirch, Germany). $\mathrm{Zn}$ and $\mathrm{Cd}$ concentrations in the extracts were measured by IPC-MS (7500ce, Agilent Technologies, Santa Clara, CA USA). Total $\mathrm{N}$ concentrations in green manure and wheat shoots and grains were determined with an NCS analyser (FlashEA 1112 Series, Thermo Fisher Scientific Inc., Waltham, MA USA).

\section{Statistical analyses}

Statistical analyses were performed using the JMP® software, Version 12.2.0 (SAS Institute Inc., Cary, NC, USA). Graphics were constructed also with JMP® or using GraphPad Prism, Version 7.0a (GraphPad Software, La Jolla, CA). Two-way and three-way analyses of variance (ANOVA) were used to test the effects of the factors (green manure addition, soil x-ray irradiation, ZSB inoculation) and their interactions. Statistical analyses were performed separately for the two soils. Tukey's HSD post hoc test was performed to further assess significances of the differences between the means. The "Fit $\mathrm{Y}$ by $X$ " function of JMP® was used for Pearson linear regressions. When needed, data were log, square root or Box-Cox transformed to fit normal distribution of their residuals which was verified using the Shapiro-Wilk W test.

\section{Results}

Characteristics of the incorporated green manure

Green manure shoots grown on and incorporated to the LOW $\mathrm{Zn}$ soil had a lower $\mathrm{N}$ concentration (25.7 $\mathrm{g} \mathrm{kg}^{-1}$ ) compared to those incorporated in the HIGH Zn soil (32.3 $\mathrm{g} \mathrm{kg}^{-1}$ ) (Table 4). Consequently, the $\mathrm{C} / \mathrm{N}$ ratio of the green manure incorporated in the LOW $\mathrm{Zn}$ soil was higher and less $\mathrm{N}$ was incorporated per $\mathrm{kg}^{-1}$ soil in the LOW $\mathrm{Zn}(67.1 \mathrm{mg} \mathrm{N})$ than in the HIGH Zn soil (95.8 mg N) (Table 4). Clover $\mathrm{Zn}$ and $\mathrm{Cd}$ concentrations were tenfold lower in the LOW $\mathrm{Zn}$ than in the HIGH $\mathrm{Zn}$ soil. Thus, far less $\mathrm{Zn}$ and $\mathrm{Cd}$ were reincorporated per $\mathrm{kg}^{-1}$ soil in the LOW $\mathrm{Zn}(20.3 \mu \mathrm{g}$ of $\mathrm{Zn}$ and $0.121 \mu \mathrm{g}$ of $\mathrm{Cd})$ compared to the HIGH Zn soil (265.9 $\mu \mathrm{g}$ of $\mathrm{Zn}$ and $1.46 \mu \mathrm{g}$ of Cd) 
Table 4 Characteristics of the green manure (Trifolium alexandrinum L.) grown in situ for 6 weeks in the HIGH Zn and the LOW Zn soils

\begin{tabular}{|c|c|c|c|c|c|c|c|c|}
\hline \multirow[b]{2}{*}{ Soil } & \multicolumn{4}{|c|}{ Green manure element concentration ${ }^{\mathrm{a}}$} & \multicolumn{4}{|c|}{$\begin{array}{l}\text { Incorporated with green manure shoots } \mathrm{kg}^{-1} \\
\text { soil }\end{array}$} \\
\hline & $\mathrm{C} / \mathrm{N}$ ratio & $\begin{array}{l}\mathrm{N} \\
\left(\mathrm{g} \mathrm{kg}^{-1}\right)\end{array}$ & $\begin{array}{l}\mathrm{Zn} \\
\left(\mathrm{mg} \mathrm{kg}^{-1}\right)\end{array}$ & $\begin{array}{l}\mathrm{Cd} \\
\left(\mu \mathrm{g} \mathrm{kg}^{-1}\right)\end{array}$ & $\begin{array}{l}\text { Biomass } \\
(\mathrm{g})\end{array}$ & $\begin{array}{l}\mathrm{N} \\
(\mathrm{mg})\end{array}$ & $\begin{array}{l}\mathrm{Zn} \\
(\mu \mathrm{g})\end{array}$ & $\begin{array}{l}\mathrm{Cd} \\
(\mu \mathrm{g})\end{array}$ \\
\hline HIGH Zn & $12.7 \pm 0.1$ & $32.3 \pm 0.4$ & $93.1 \pm 2.1$ & 490.2 & 2.97 & 95.8 & 276.5 & 1.46 \\
\hline LOW Zn & $15.6 \pm 0.2$ & $25.7 \pm 0.4$ & 8.0 & 46.2 & 2.61 & 67.1 & 21.6 & 0.121 \\
\hline
\end{tabular}

Before incorporation, clover shoots were harvested and pooled in two green manure samples (one produced in the HIGH $\mathrm{Zn}$ and one in the LOW Zn soil). Total C, N, Zn and Cd analyses were performed on these two representative samples. Values after the means within a column correspond to the standard errors of the analytical replicates

${ }^{\mathrm{a}} \mathrm{C} / \mathrm{N}$ ratio and $\mathrm{N}$ values are means of five analytical replicates. $\mathrm{Zn}$ and $\mathrm{Cd}$ values are means of two to four analytical replicates (except for Cd concentration in LOW $\mathrm{Zn}$ where only one value was available). No standard deviation was calculated when two analytical replicates were analyzed

(Table 4). These amounts do not include the N, Zn and $\mathrm{Cd}$ incorporated with the green manure roots.

Soil $\mathrm{N}$ and biological parameters

ANOVA tests revealed significant green manure and soil $\mathrm{x}$-ray irradiation effects on soil $\mathrm{pH}$ at wheat planting in the HIGH $\mathrm{Zn}$ soil (Table 5) and in both soils at wheat flowering (Table 6). However, differences in soil $\mathrm{pH}$ means were small (i.e. 0.1 to $0.3 \mathrm{pH}$ units) and were therefore considered as irrelevant. Total soil $\mathrm{N}$ was significantly increased by the incorporation of green manure in both soils at wheat planting (Table 5) and wheat flowering (Table 6). At wheat planting, this increase of ca. $80 \mathrm{mg} \mathrm{N}$ corresponded nearly to the amount of $\mathrm{N}$ added with the green manure (95.8 $\mathrm{mg} \mathrm{N})$. In both soils, soil x-ray irradiation did not affect total soil $\mathrm{N}$ at wheat planting (Table 5) but decreased it at wheat flowering (Table 6).

At wheat planting, soil $\mathrm{NO}_{3}{ }^{-}$concentrations (but not $\mathrm{NH}_{4}{ }^{+}$) were lower in the $+\mathrm{GM}$ than in the NO GM treatments (Table 5). This resulted in lower total soil mineral $\mathrm{N}$ concentrations in the $+\mathrm{GM}$ compared to the NO GM treatments in both the HIGH $\mathrm{Zn}$ and the LOW Zn soils at wheat planting. This was also the case at wheat flowering in the LOW Zn (Fig. 1B) but not in the HIGH Zn soil (Fig. 1A) (see Table S1 for three-way ANOVA of mineral $\mathrm{N}$ concentrations at wheat flowering). Mineral $\mathrm{N}$ concentrations were lower in the LOW $\mathrm{Zn}$ compared to those found in the HIGH Zn soil at wheat flowering (Fig. 1).
In the $\mathrm{HIGH} \mathrm{Zn}$ soil, lower $\mathrm{NO}_{3}^{-}$and higher $\mathrm{NH}_{4}{ }^{+}$concentrations were found in the X-RAY IRR compared to the NO IRR treatments at wheat planting (Table 5) and wheat flowering (Fig. 1). In this soil, this was accompanied by higher mineral $\mathrm{N}$ concentrations in the X-RAY IRR compared to the NO IRR treatments at both of these time points. On the other hand, in the LOW Zn soil, there were similar levels of $\mathrm{NO}_{3}{ }^{-}$in the X-RAY IRR and the NO IRR treatments and $\mathrm{NH}_{4}{ }^{+}$concentrations were only increased by soil $x$-ray irradiation in the + GM treatments at wheat planting (Table 5). As for the HIGH Zn soil, lower $\mathrm{NO}_{3}^{-}$concentrations were found in the X-RAY IRR compared to the NO IRR treatments of the LOW $\mathrm{Zn}$ soil at wheat flowering (Fig. 1) and at this time point $\mathrm{NH}_{4}{ }^{+}$was either entirely depleted (in NO IRR) or very low (in X-RAY IRR).

Soil respiration and microbial $\mathrm{C}$ biomass were increased by the incorporation of green manure in both the HIGH Zn and the LOW Zn soils (Table 6). Soil respiration was also increased by soil $\mathrm{x}$-ray irradiation while microbial $\mathrm{C}$ biomass was lower in the X-RAY IRR compared to the NO IRR treatments in both soils (Table 6). ZSB inoculation had no significant effects on soil $\mathrm{pH}$, total soil $\mathrm{N}$, microbial $\mathrm{C}$ biomass and soil respiration (except in the HIGH Zn soil where ZSB inoculation significantly decreased soil respiration in + GM_X-RAY IRR) (Table 6). Likewise, ZSB inoculation did not affect soil mineral $\mathrm{N}$ concentrations at wheat flowering (Fig. 1). 


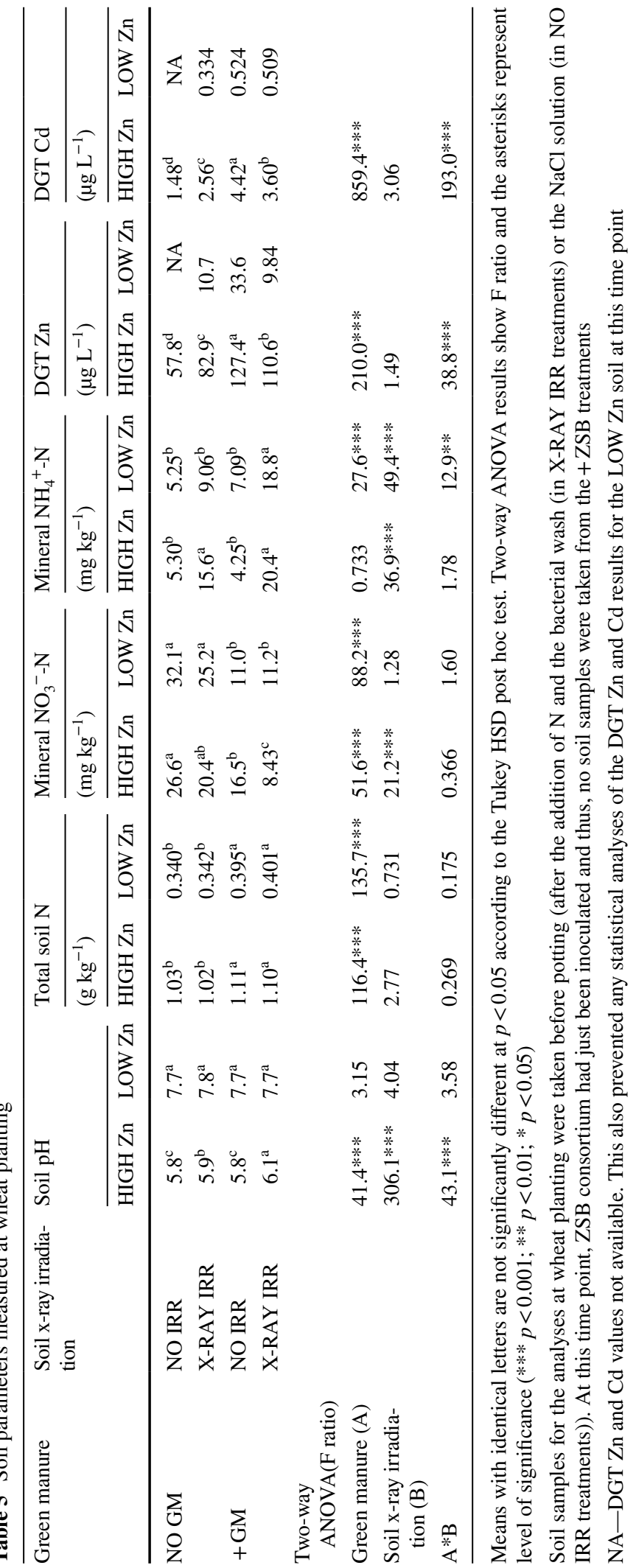




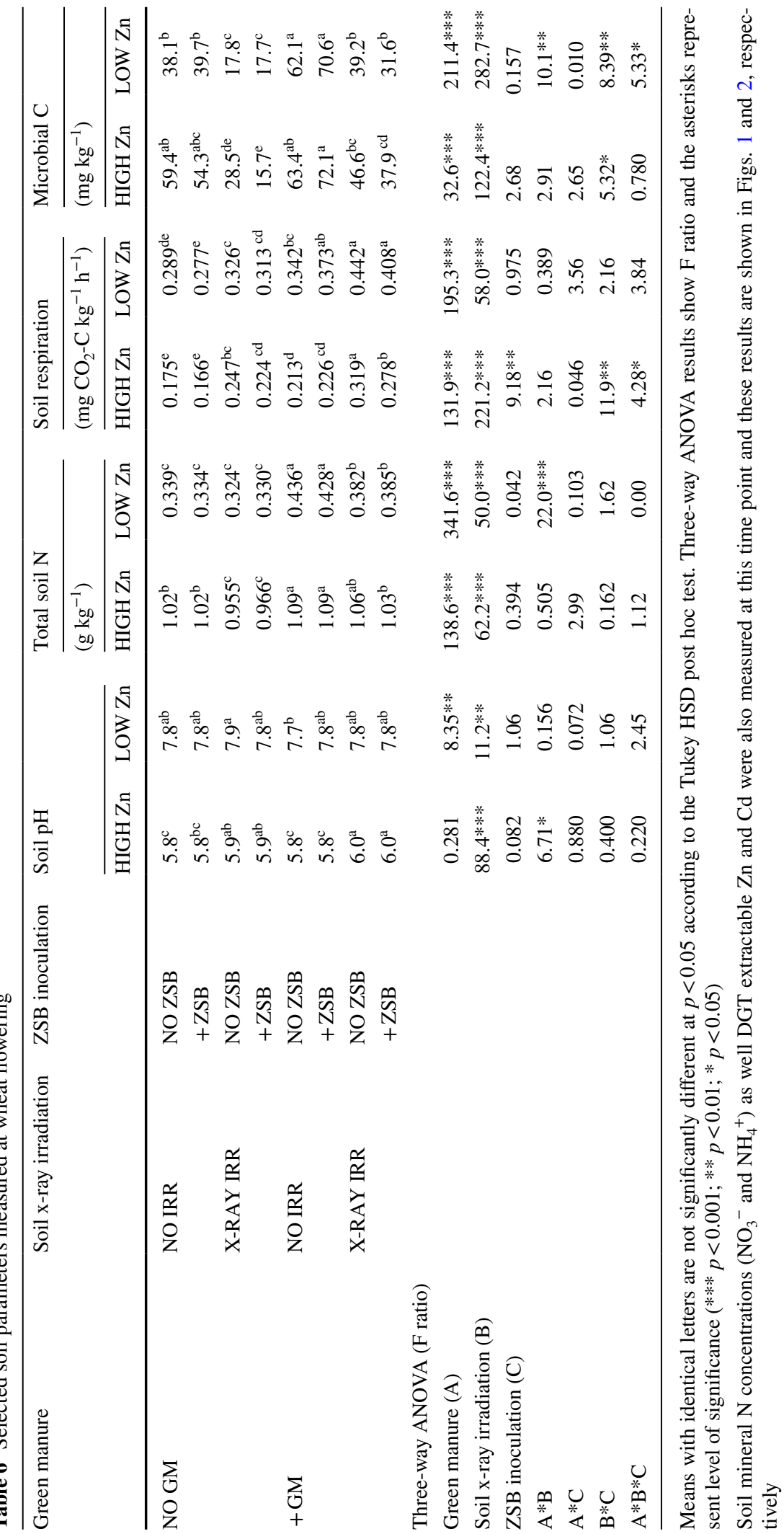



and $\mathrm{NH}_{4}^{+}$) at wheat flowering in the HIGH Zn (A) and the LOW $\mathrm{Zn}(\mathbf{B})$ soil. Bar plots represent stacked $\mathrm{NH}_{4}{ }^{+}$and $\mathrm{NO}_{3}{ }^{-}$means with their associated standard errors $(n=4)$. Plots with identical letters are not significantly different at $p<0.05$ according to the Tukey HSD post hoc test (performed on the total mineral $\mathrm{N}$ data separately for HIGH $\mathrm{Zn}$ and LOW Zn)
Fig. 1 Mineral $\mathrm{N}\left(\mathrm{NO}_{3}^{-}\right.$

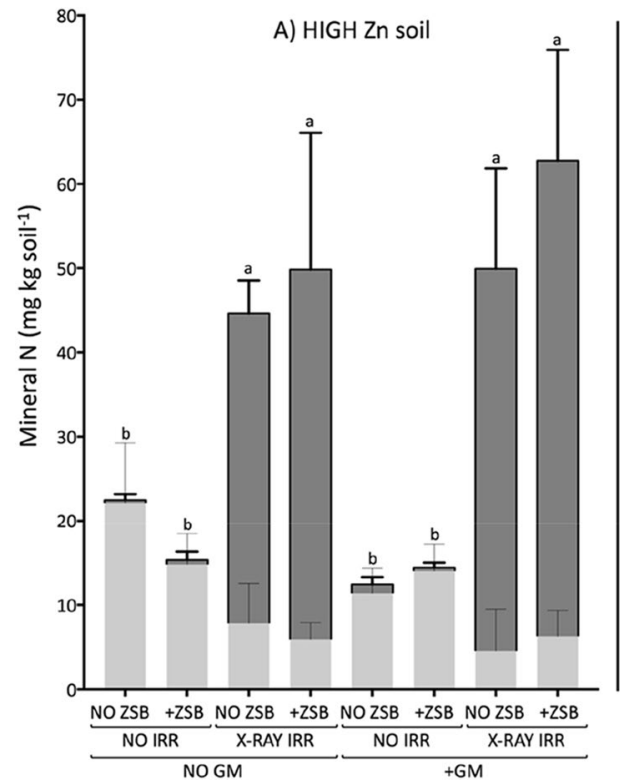

B) LOW Zn soil

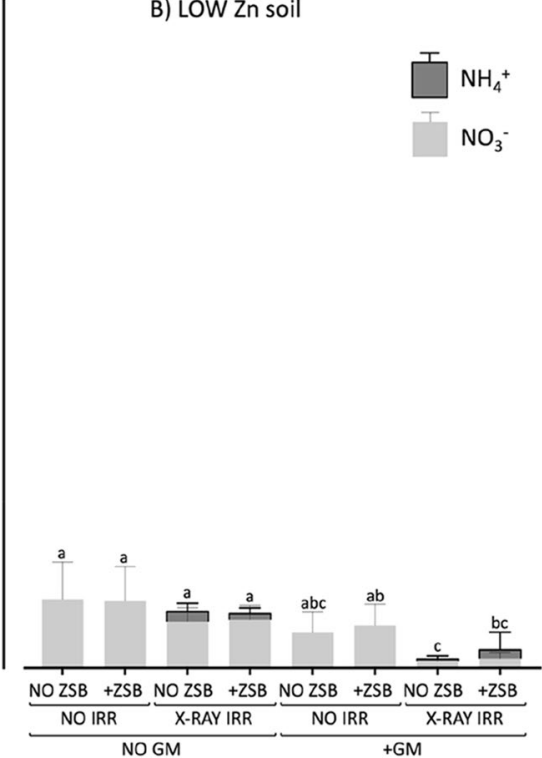

A) HIGH Zn soil

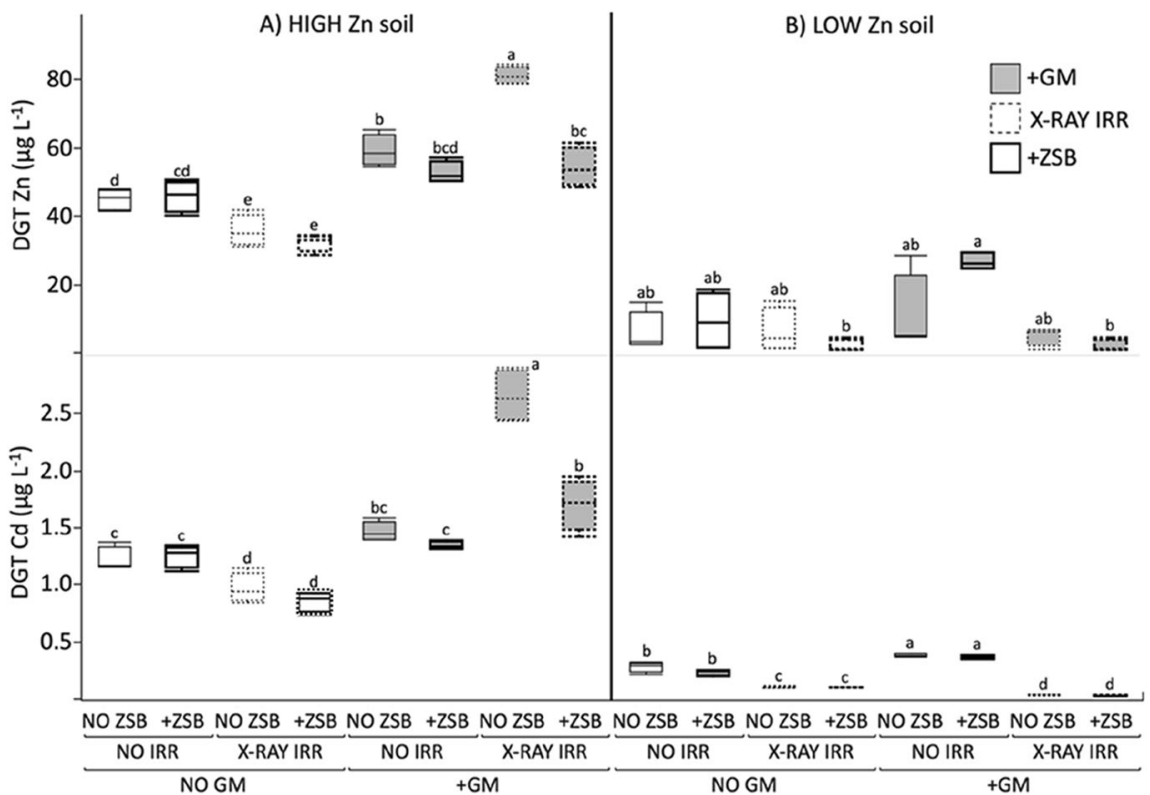

Fig. 2 DGT extractable soil $\mathrm{Zn}$ and $\mathrm{Cd}$ at wheat flowering in the HIGH Zn (A) and the LOW Zn $(\mathbf{B})$ soil $(n=4)$. Box plots with identical letters are not significantly different at $\mathrm{p}<0.05$ according to the Tukey HSD post hoc test (performed four times separately on DGT $\mathrm{Zn}$ and Cd data for HIGH $\mathrm{Zn}$ and LOW $\mathrm{Zn}$ ). Boxes filled with grey represent treatments where green manure had been incorporated before wheat planting (+GM). Dashed boxes represent treatments where soil was $\mathrm{X}$-ray irradiated and re-inoculated with native soil bacteria exclusively (X-RAY IRR). Thick black boxes represent pots where ZSB were inoculated $(+\mathrm{ZSB})$ 
No mycorrhizal structures were found on wheat roots sampled at wheat flowering in any of the treatments (data not shown).

Soil $\mathrm{Zn}$ and Cd extractable with diffusive gradients in thin films (DGT)

In the HIGH $\mathrm{Zn}$ soil, DGT extractable $\mathrm{Zn}$ and $\mathrm{Cd}$ were the highest in the $+\mathrm{GM}$ treatments at wheat planting (Table 5) and flowering (Fig. 2A) (see Table S1 for three-way ANOVA of DGT Zn and Cd at wheat flowering). At wheat planting, HIGH Zn soil $\mathrm{x}$-ray irradiation increased DGT $\mathrm{Zn}$ and $\mathrm{Cd}$ in the NO GM but decreased these soil parameters in the + GM treatments (Table 5). Soil x-ray irradiation had the opposite effect at wheat flowering in the HIGH Zn soil as it decreased DGT $\mathrm{Zn}$ and $\mathrm{Cd}$ in the NO GM but increased these same parameters in the $+\mathrm{GM}$ treatments (Fig. 2A). Consequently, in this soil, DGT $\mathrm{Zn}$ and Cd levels were much higher in the + GM_XRAY IRR compared to what was found in any of the other treatments at wheat flowering. In the HIGH Zn soil, while ZSB inoculation did not affect DGT $\mathrm{Zn}$ and $\mathrm{Cd}$ in the NO GM, it decreased these parameters in the +GM treatments (Fig. 2A). This was the most striking in +GM_X-RAY IRR, where ZSB inoculation decreased DGT Zn and Cd by up to $35 \%$ (Fig. 2A).

In the LOW $\mathrm{Zn}$ soil, DGT $\mathrm{Zn}$ and $\mathrm{Cd}$ values were much lower compared to those observed in the HIGH $\mathrm{Zn}$ soil and these were even lower in the X-RAY IRR treatments at wheat flowering (Fig. 2B). The incorporation of green manure to the LOW $\mathrm{Zn}$ soil increased DGT $\mathrm{Zn}$ and $\mathrm{Cd}$ at wheat flowering in the NO IRR treatments, although this increase was significant only for DGT Cd (Fig. 2B). In contrast to what was observed in the HIGH $\mathrm{Zn}$ soil at wheat flowering, the lowest DGT Cd values in the LOW Zn soil were found in the + GM_X-RAY IRR treatments and ZSB inoculation had no effect on DGT extractable $\mathrm{Zn}$ and Cd (Fig. 2B).

Pearson correlations were further investigated between DGT $\mathrm{Zn}$ or $\mathrm{Cd}$ and soil $\mathrm{pH}$, total soil $\mathrm{N}$ and mineral $\mathrm{N}$ concentrations, soil respiration and microbial $\mathrm{C}$ biomass at wheat flowering (Table S2). For the X-RAY IRR treatments of the HIGH Zn soil, strong positive relationships were found between DGT extractable $\mathrm{Zn}$ and total soil $\mathrm{N}(r=0.88 ; p<0.001)$, soil respiration $(r=0.89 ; p<0.001)$ and microbial $\mathrm{C}$ biomass $(r=0.80 ; p<0.001)$ (Table S2 and Fig S1). For the NO IRR treatments in the HIGH Zn soil, positive but weaker correlations were found between DGT extractable $\mathrm{Zn}$ and total soil $\mathrm{N}(r=0.78 ; p<0.001)$ and soil respiration $(r=0.65 ; p<0.01)$. Correlation results obtained between DGT extractable $\mathrm{Cd}$ and the above-mentioned soil biochemical parameters were very similar to the once observed for DGT extractable $\mathrm{Zn}$ in the X-RAY IRR and the NO IRR treatments in the HIGH Zn soil. In the non-irradiated LOW Zn soil, DGT extractable Cd (but not Zn) was significantly positively correlated with total soil $\mathrm{N}$, soil respiration and microbial $\mathrm{C}$ biomass (Table $\mathrm{S} 2$ ). Opposite results were found for the DGT extractable Cd in the x-ray irradiated LOW Zn, because there was far less DGT $\mathrm{Cd}$ in the + GM compared to the NO GM treatments of the X-ray irradiated LOW Zn (Fig. 2B).

Wheat growth and element accumulation

There was a trend toward lower wheat shoot biomass in the + GM compared to the NO GM treatments in the HIGH Zn (at wheat maturity (Table 7)) and in the LOW Zn soil (both at wheat flowering (Table S3) and wheat maturity (Table 7)). Similarly, in the HIGH $\mathrm{Zn}$ soil, grain biomass (Table 7) and the number of grains produced per $\mathrm{kg} \mathrm{soil}^{-1}$ (Table S4) tended to be lower with green manure incorporation. On the other hand, in the LOW Zn soil, the highest grain biomass (Table 7) and number of grains produced per $\mathrm{kg}$ soil $^{-1}$ (Table S4) were observed in the + GM_X-RAY IRR treatments. In none of the two soils, the incorporation of green manure affected wheat root biomass at wheat maturity (Table 7).

Unlike green manure incorporation, soil x-ray irradiation had strong effects on wheat biomass production. In the HIGH Zn and the LOW Zn soil, soil x-ray irradiation increased wheat shoot biomass at flowering (Table S3) and also wheat shoot, grain and root biomass at maturity (Table 7). Moreover, at wheat maturity, a higher number of ears per plant and grains produced per $\mathrm{kg} \mathrm{soil}^{-1}$ was observed in the X-RAY IRR compared to the NO IRR treatments (Table S4).

In both soils, wheat $\mathrm{Zn}$ concentrations were not (or marginally) increased by the incorporation of green manure at wheat flowering (Fig S2) and wheat maturity (Figs. 3 and 4) (see Table S5 for three-way ANOVA of shoot and grain $\mathrm{Zn}, \mathrm{Cd}$ and $\mathrm{N}$ concentrations at maturity). In contrast, wheat shoot and grain 
Table 7 Wheat shoot, grain and root biomass at maturity

\begin{tabular}{|c|c|c|c|c|c|c|c|c|}
\hline \multirow[t]{3}{*}{ Green manure } & \multirow[t]{3}{*}{ Soil x-ray irradiation } & \multirow[t]{3}{*}{ ZSB inoculation } & \multirow{2}{*}{\multicolumn{2}{|c|}{$\frac{\text { Shoot biomass }}{\left(\mathrm{g} \mathrm{kg} \mathrm{soil}^{-1}\right)}$}} & \multirow{2}{*}{\multicolumn{2}{|c|}{$\frac{\text { Grain biomass }}{\left(\mathrm{g} \mathrm{kg} \mathrm{soil}^{-1}\right)}$}} & \multirow{2}{*}{\multicolumn{2}{|c|}{$\frac{\text { Root biomass }}{\left(\mathrm{g} \mathrm{kg} \mathrm{soil}^{-1}\right)}$}} \\
\hline & & & & & & & & \\
\hline & & & HIGH Zn & LOW Zn & $\mathrm{HIGH} \mathrm{Zn}$ & LOW Zn & HIGH Zn & LOW Zn \\
\hline \multirow[t]{4}{*}{ NO GM } & \multirow[t]{2}{*}{ NO IRR } & NO ZSB & $1.63^{\mathrm{ab}}$ & $1.87^{\mathrm{abc}}$ & $2.24^{\mathrm{ab}}$ & $1.56^{\mathrm{abc}}$ & $0.214^{\mathrm{abc}}$ & $0.349^{\mathrm{ab}}$ \\
\hline & & $+\mathrm{ZSB}$ & $1.44^{\mathrm{b}}$ & $1.66^{\mathrm{bc}}$ & $2.13^{\mathrm{ab}}$ & $1.16^{\mathrm{c}}$ & $0.167^{\mathrm{bc}}$ & $0.267^{\mathrm{b}}$ \\
\hline & \multirow[t]{2}{*}{ X-RAY IRR } & NO ZSB & $1.83^{\mathrm{a}}$ & $2.17^{\mathrm{a}}$ & $2.45^{\mathrm{a}}$ & $1.52^{\mathrm{abc}}$ & $0.272^{\mathrm{ab}}$ & $0.394^{\mathrm{ab}}$ \\
\hline & & $+\mathrm{ZSB}$ & $1.82^{\mathrm{a}}$ & $1.95^{\mathrm{ab}}$ & $2.50^{\mathrm{a}}$ & $1.60^{\mathrm{abc}}$ & $0.289^{\mathrm{a}}$ & $0.522^{\mathrm{a}}$ \\
\hline \multirow[t]{4}{*}{$+\mathrm{GM}$} & \multirow[t]{2}{*}{ NO IRR } & NO ZSB & $1.41^{\mathrm{b}}$ & $1.54^{\mathrm{c}}$ & $2.10^{\mathrm{ab}}$ & $1.54^{\mathrm{abc}}$ & $0.154^{\mathrm{c}}$ & $0.314^{\mathrm{ab}}$ \\
\hline & & $+\mathrm{ZSB}$ & $1.43^{\mathrm{b}}$ & $1.52^{\mathrm{c}}$ & $1.67^{\mathrm{b}}$ & $1.42^{\mathrm{bc}}$ & $0.170^{\mathrm{abc}}$ & $0.303^{\mathrm{ab}}$ \\
\hline & \multirow[t]{2}{*}{ X-RAY IRR } & NO ZSB & $1.63^{\mathrm{ab}}$ & $1.95^{\mathrm{ab}}$ & $2.26^{\mathrm{a}}$ & $1.93^{\mathrm{a}}$ & $0.254^{\mathrm{abc}}$ & $0.403^{\mathrm{ab}}$ \\
\hline & & $+\mathrm{ZSB}$ & $1.63^{\mathrm{ab}}$ & $1.91^{\mathrm{abc}}$ & $2.34^{\mathrm{a}}$ & $1.89^{\mathrm{ab}}$ & $0.218^{\mathrm{abc}}$ & $0.396^{\mathrm{ab}}$ \\
\hline \multicolumn{9}{|c|}{ Three-way ANOVA (F ratio) } \\
\hline \multicolumn{3}{|c|}{ Green manure (A) } & $9.72 * *$ & $8.98 * *$ & $6.28 *$ & $10.2 * *$ & 3.80 & 0.641 \\
\hline \multicolumn{3}{|c|}{ Soil x-ray irradiation (B) } & $25.2 * * *$ & $32.1 * * *$ & $15.1 * * *$ & $18.5 * * *$ & $24.1 * * *$ & $11.1 * *$ \\
\hline \multicolumn{3}{|c|}{ ZSB inoculation (C) } & 0.709 & 4.00 & 0.583 & 2.50 & 0.723 & 0.038 \\
\hline \multicolumn{3}{|l|}{$\mathrm{A} * \mathrm{~B}$} & 0.591 & 0.832 & 0.050 & 2.38 & 0.00 & 0.656 \\
\hline \multicolumn{3}{|l|}{$\mathrm{A}^{*} \mathrm{C}$} & 1.27 & 2.28 & 0.134 & 0.278 & 0.308 & 0.198 \\
\hline \multicolumn{3}{|l|}{$\mathrm{B} * \mathrm{C}$} & 0.809 & 0.020 & 2.51 & 3.73 & 0.033 & 2.19 \\
\hline \multicolumn{3}{|l|}{$\mathrm{A} * \mathrm{~B} * \mathrm{C}$} & 1.00 & 0.008 & 0.324 & 1.68 & 2.94 & 2.03 \\
\hline
\end{tabular}

Means with identical letters are not significantly different at $p<0.05$ according to the Tukey HSD post hoc test. Three-way ANOVA results show $\mathrm{F}$ ratio and the asterisks represent level of significance $(* * * p<0.001 ; * * p<0.01 ; * p<0.05)$

Cd concentrations was decreased by the incorporation of green manure in the HIGH Zn (only in X-RAY IRR) (Fig. 3) and in the LOW Zn soil in all the treatments (Fig. 4). In the LOW Zn soil, green manure addition tended to decrease shoot and grain $\mathrm{N}$ concentrations (Fig. 4).

In the HIGH $\mathrm{Zn}$ soil, shoots and grain $\mathrm{Zn}, \mathrm{Cd}$ and $\mathrm{N}$ concentrations were generally higher in the X-RAY IRR than in the NO IRR treatments (except for Cd concentrations, which decreased with the incorporation of green manure in the X-RAY IRR treatments) (Fig. 3). Consequently, in this soil, wheat took up more $\mathrm{Zn}, \mathrm{Cd}$ and $\mathrm{N}$ in the X-RAY IRR than in the NO IRR treatments (see also $\mathrm{Zn}, \mathrm{Cd}$ and $\mathrm{N}$ uptake in Table S6). In the LOW Zn soil, element concentrations were either unaffected (for $\mathrm{Zn}$ ) or slightly increased by soil $\mathrm{x}$-ray irradiation $(\mathrm{Cd}$ and $\mathrm{N}$ concentrations) (Fig. 4). Thus, as in the HIGH Zn soil, uptakes of $\mathrm{Zn}, \mathrm{Cd}$ and $\mathrm{N}$ from irradiated LOW $\mathrm{Zn}$ were generally higher than in the NO IRR treatments (Table S6). In both soils, ZSB inoculation did neither affect wheat growth, nor element concentrations (Figs. 3 and 4).
For the HIGH $\mathrm{Zn}$ soil, positive correlations were found between concentrations of $\mathrm{N}$ and $\mathrm{Zn}$ in the wheat shoots at flowering $(r=0.70 ; p<0.001)$ and in the wheat grains at maturity $(r=0.62 ; p<0.001)$ (Table 8). No correlations between shoot and grain $\mathrm{N}$ and $\mathrm{Cd}$ concentrations were found for the wheat grown in this soil due to the lower wheat $\mathrm{Cd}$ concentrations observed in the + GM_X-RAY IRR treatments (Fig. 3). For the LOW Zn soil, except for the shoot $\mathrm{Zn}$ concentrations at wheat flowering, shoot and grain $\mathrm{N}$ and $\mathrm{Zn}$ and $\mathrm{Cd}$ concentrations were positively correlated at wheat flowering and maturity (Table 8).

\section{Discussion}

Soil x-ray irradiation increased soil mineral N, wheat growth and element accumulation

In the HIGH $\mathrm{Zn}$ soil, $\mathrm{x}$-ray irradiation increased soil $\mathrm{NH}_{4}{ }^{+}$concentrations considerably, which resulted in higher total mineral soil $\mathrm{N}$ concentrations in the X-RAY IRR compared to the NO IRR treatments 


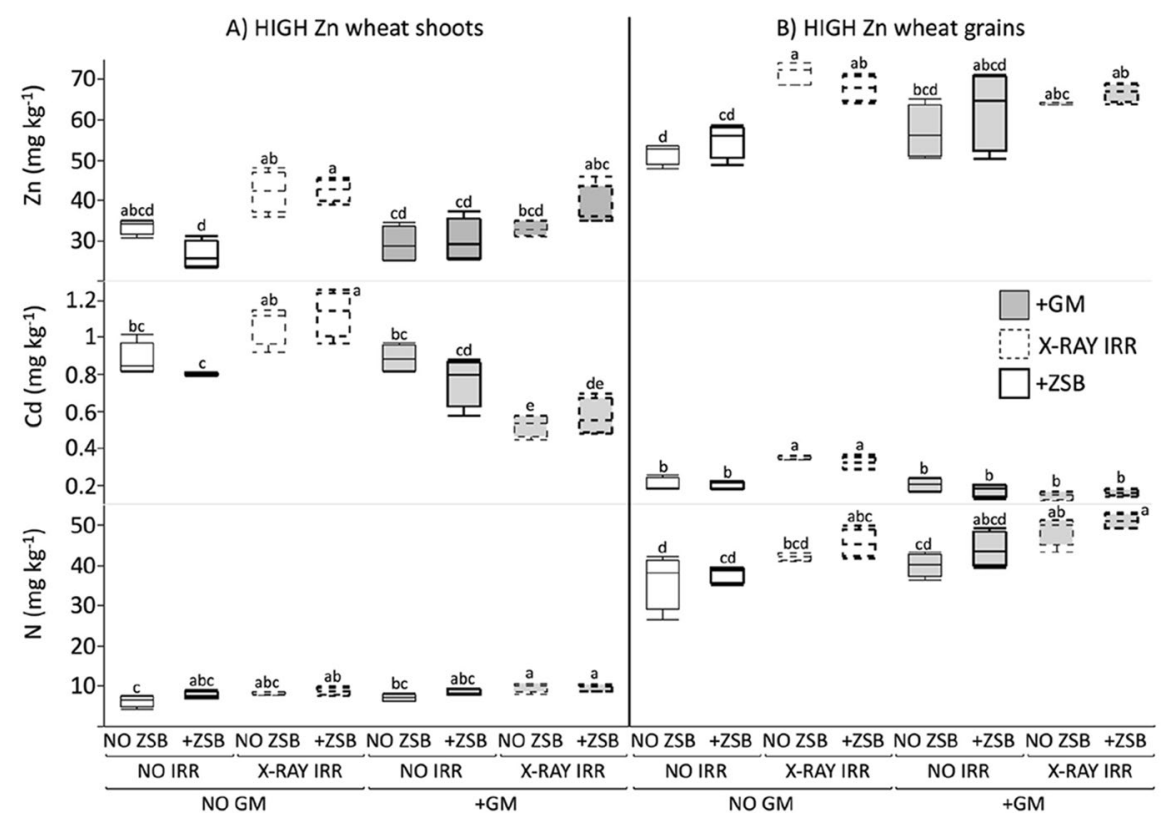

Fig. 3 Wheat shoot (A) and grain (B) Zn, Cd and N concentrations at maturity in the HIGH Zn soil. Box plots with identical letters are not significantly different at $p<0.05$ according to the Tukey HSD post hoc test (performed six times separately on $\mathrm{Zn}, \mathrm{Cd}$ and $\mathrm{N}$ data for HIGH $\mathrm{Zn}$ wheat shoots and grains). Boxes filled with grey represent treatments where green

at wheat planting (Table 5) and wheat flowering (Fig. 1). Wheat grown in the irradiated HIGH Zn soil benefited from the increased $\mathrm{N}$ availability, by producing more biomass (including root) and accumulating more $\mathrm{N}$ in their tissues. This might have also been the case for the wheat grown in the irradiated LOW $\mathrm{Zn}$ soil, although differences in mineral $\mathrm{N}$ concentrations were no longer visible at wheat flowering. These irradiation effects can potentially explain the higher $\mathrm{N}, \mathrm{Zn}$ and $\mathrm{Cd}$ uptake in the X-RAY IRR compared to the NO IRR treatments (Table S6). Indeed, increased root biomass (i.e. more roots and root hairs) might have enhanced wheat access to $\mathrm{Zn}$ and $\mathrm{Cd}$ in soil and higher wheat $\mathrm{N}$ concentrations could have promoted the synthesis of $\mathrm{N}$ rich compounds involved in trace element uptake and translocation within the plant (Palmer and Guerinot 2009). Soil irradiation was also reported to increase the availability of other macronutrients (e.g. P and sulfur) (McNamara et al. 2003) and to eliminate phytopathogens (Thompson 1990), which could contribute to higher biomass production and element uptake in the X-RAY IRR compared to the NO IRR treatments. manure had been incorporated before wheat planting (+GM). Dashed boxes represent treatments where soil was X-ray irradiated and re-inoculated with native soil bacteria exclusively (X-RAY IRR). Thick black boxes represent pots where ZSB were inoculated $(+\mathrm{ZSB})$

In previous studies, increased mineral $\mathrm{N}$ upon soil irradiation was attributed to microbial lysis and the subsequent release of $\mathrm{N}$ and $\mathrm{N}$ mineralizing enzymes (e.g. protease and deaminase) (Lensi et al. 1991; Salonius et al. 1967). As observed in our experiment, decrease in $\mathrm{NO}_{3}{ }^{-}$upon soil irradiation has often been reported and the underlying biochemical mechanisms are not fully understood (McNamara et al. 2003), although this may partly be attributed to the elimination of the nitrifiers.

One might have expected the wheat grown in NO IRR to establish symbiosis with AM fungi (but not in the X-RAY IRR soils, free of fungi). However, no mycorrhizal structures were found on wheat roots sampled at wheat flowering in any of the treatments, probably because of the initial soil $\mathrm{P}$ addition which might have inhibited root-mycorrhizal associations (Nouri et al. 2014). Alternatively, extensive soil storage over several years coupled with high disturbance such as drying and sieving may also have diminished the infective potential of the soils. 


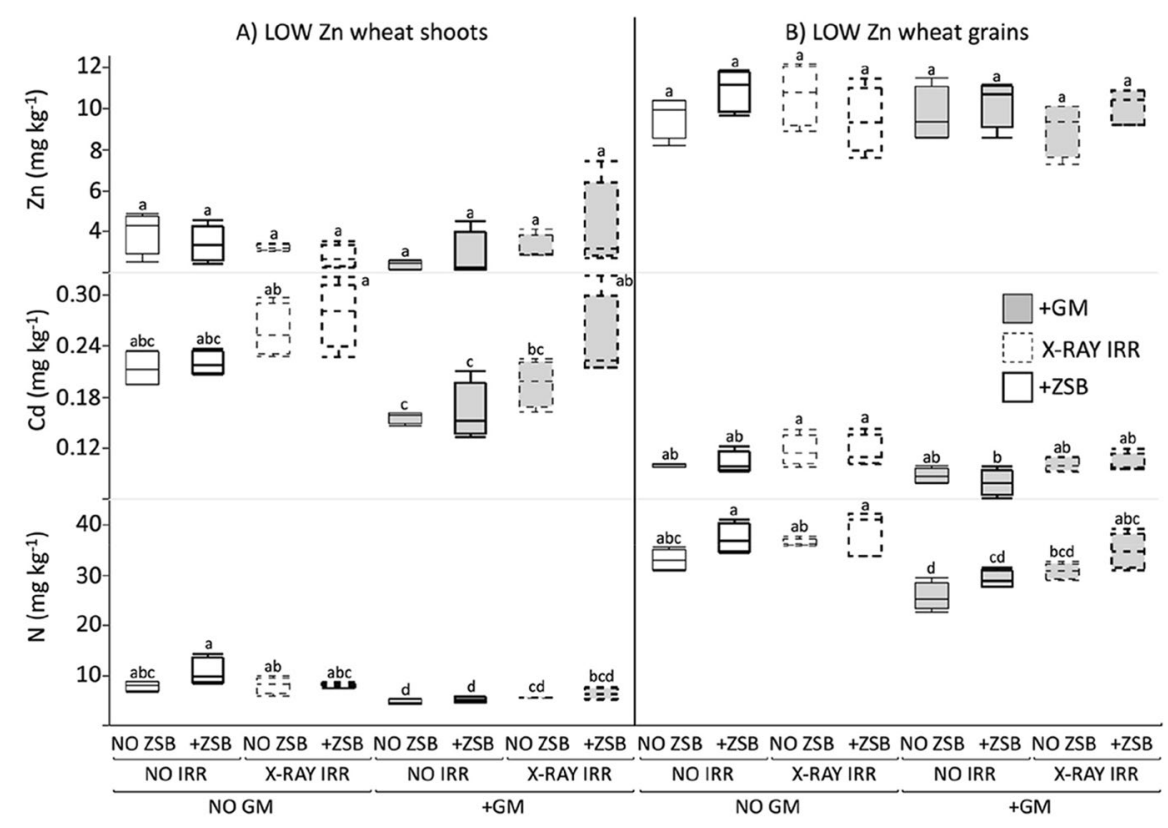

Fig. 4 Wheat shoot (A) and grain (B) $\mathrm{Zn}, \mathrm{Cd}$ and $\mathrm{N}$ concentrations at maturity in the LOW Zn soil. Box plots with identical letters are not significantly different at $p<0.05$ according to the Tukey HSD post hoc test (performed six times separately on $\mathrm{Zn}, \mathrm{Cd}$ and $\mathrm{N}$ data for LOW $\mathrm{Zn}$ wheat shoots and grains). Boxes filled with grey represent treatments where green manure had been incorporated before wheat planting (+GM). Dashed boxes represent treatments where soil was X-ray irradiated and re-inoculated with native soil bacteria exclusively (X-RAY IRR). Thick black boxes represent pots where ZSB were inoculated $(+\mathrm{ZSB})$

Table 8 Pearson correlation coefficient (r) between $\mathrm{N}, \mathrm{Zn}$ and $\mathrm{Cd}$ in wheat shoots and grains considering all the treatments for both soils separately

\begin{tabular}{|c|c|c|c|c|c|c|c|}
\hline & & \multirow{2}{*}{\multicolumn{2}{|c|}{$\frac{\text { Wheat flowering }}{\text { Shoot } \mathrm{N}}$}} & \multicolumn{4}{|c|}{ Wheat maturity } \\
\hline & & & & \multicolumn{2}{|l|}{ Shoot N } & \multicolumn{2}{|l|}{ Grain $N$} \\
\hline & & HIGH Zn & LOW Zn & HIGH Zn & LOW Zn & HIGH Zn & LOW Zn \\
\hline \multirow[t]{2}{*}{ Wheat flowering } & Shoot Zn & $0.70 * * *$ & 0.29 & & & & \\
\hline & Shoot Cd & -0.23 & $0.44 *$ & & & & \\
\hline \multirow[t]{4}{*}{ Wheat maturity } & Shoot Zn & & & 0.27 & $0.42 *$ & & \\
\hline & Shoot Cd & & & -0.33 & $0.62 * * *$ & & \\
\hline & Grain Zn & & & & & $0.62 * * *$ & $0.43^{*}$ \\
\hline & Grain Cd & & & & & -0.34 & $0.42^{*}$ \\
\hline
\end{tabular}

Asterisks in superscript indicate correlation probability with $* p<0.05 ; * * p<0.01$ and $* * * p<0.001$

The incorporation of green manure increased soil $\mathrm{Zn}$ and $\mathrm{Cd}$ availability

Lower DGT extractable $\mathrm{Zn}$ and $\mathrm{Cd}$, as well as reduced total soil $\mathrm{N}$ concentrations at wheat flowering in the X-RAY IRR soils might be due to the higher wheat uptake of $\mathrm{Zn}, \mathrm{Cd}$ and $\mathrm{N}$ in these treatments compared to those found in the NO IRR soils. In the HIGH Zn soil, there was however one exception to this, in the irradiated treatments incorporated with green manure (+GM_X-RAY IRR), where the highest DGT extractable $\mathrm{Zn}$ and Cd were measured. For $\mathrm{Zn}$, this cannot be explained by lower wheat uptake, as the uptake of $\mathrm{Zn}$ was similar or higher in 
the + GM_X-RAY IRR than in the other treatments (Table S6). Green manure residue decomposition provided soil bacteria (presumably dominant in X-RAY IRR, since these treatments corresponded to sterilized soil re-inoculated with a bacterial wash) with $\mathrm{N}$ and $\mathrm{C}$, thereby stimulating their metabolic activity (Marschner and Bredow 2002). Increased bacterial activity due to the incorporation of green manure might have promoted the mobilization of $\mathrm{Zn}$ and $\mathrm{Cd}$ through the production of various metabolic compounds involved in trace element mobilization such as organic acids (e.g. gluconic, citric, malic and oxalic acid) (Costerousse et al. 2018; Fasim et al. 2002; Li et al. 2010) and metal chelating siderophores (Brandel et al. 2012). The strong and positive correlation observed between DGT Zn and Cd and soil bacterial activity (i.e. soil respiration and microbial $\mathrm{C}$ ) in irradiated HIGH $\mathrm{Zn}$ supports the concept that bacterial activity was intimately associated with $\mathrm{Zn}$ and Cd mobilization in this soil (Fig S1). Furthermore, the absence of fungi and soil fauna in the X-RAY IRR treatments (which probably explains lower microbial biomass in these soils), might also have benefited to soil bacterial activity through reduced trophic competition. Accordingly, soil respiration levels in these treatments were higher compared to the NO IRR treatments.

The important amount of DGT extractable $\mathrm{Zn}$ released in the +GM_X-RAY IRR treatments of the HIGH Zn soil (measured only in NO ZSB) may account for the decrease in $\mathrm{Cd}$ accumulation in wheat shoots and grains in these treatments (Fig. 3), due to competition for the same root and phloem cell membrane transporters (Hart et al. 2002). This was not observed in the LOW Zn soil, probably because the amount of $\mathrm{Zn}$ released in the $+\mathrm{GM}$ treatments of this soil was not sufficient to cause the same effect on wheat $\mathrm{Cd}$ uptake. $\mathrm{Zn}$ is known to be more efficiently transported towards the above ground biomass compared to $\mathrm{Cd}$ which tends to accumulate in the roots (Wiggenhauser et al. 2016). Similarly, Cd concentrations in wheat shoots and grains was shown to be reduced by mineral $\mathrm{Zn}$ application to soil (Khoshgoftar et al. 2004; Oliver et al. 1994) and leaves (Javed et al. 2016; Sarwar et al. 2015).

Although no decrease in soil $\mathrm{pH}$ was observed in response to clover incorporation, soil microbes might have indirectly contributed to increase metal availability by releasing $\mathrm{NH}_{4}{ }^{+}$(as a result of green manure decomposition) and protons (e.g. generated by $\mathrm{NH}_{4}{ }^{+}$ nitrification). These could exchange with soil bound $\mathrm{Zn}$ and $\mathrm{Cd}$, thereby increasing metal availabilities in the treatments with green manure. Increases in soil $\mathrm{Zn}$ and $\mathrm{Cd}$ availability in the +GM_X-RAY IRR treatments of the HIGH Zn soil, as well as in all the treatments where clover had been incorporated, cannot be attributed solely to changes in soil microbial activity. For instance, in the X-RAY IRR treatments, the radiations might have (at least partly) released $\mathrm{N}$ immobilized by soil microbes in the presence of green manure (estimated around 15 to $20 \mathrm{mg} \mathrm{N}$ per $\mathrm{kg} \mathrm{soil}{ }^{-1}$ at wheat planting, considering a microbial $\mathrm{C} / \mathrm{N}$ ratio of five and multiplying microbial $\mathrm{N}$ by a factor of two to account for non-extractable microbial N (Jenkinson et al. 2004)), thereby amplifying Zn and $\mathrm{Cd}$ mobilization by exchange mechanisms with $\mathrm{NH}_{4}{ }^{+}$. Microbial lysis in the irradiated treatments might have also released $\mathrm{N}$ mineralizing enzymes (e.g. protease and deaminase) that remain active after the irradiation treatment (Lensi et al. 1991), which could explain further release of $\mathrm{NH}_{4}{ }^{+}$and thus higher $\mathrm{Zn}$ and Cd availabilities in the + GM_X-RAY IRR treatments. The increase in $\mathrm{Zn}$ and $\mathrm{Cd}$ availability following the incorporation of green manure could also originate from the release of $\mathrm{Zn}$ mobilizing ligands from decomposing green manure residues such as dissolved organic $\mathrm{C}$ and amino acids (Gramlich et al. 2013; Soltani et al. 2014). Positive correlations were indeed previously reported between dissolved organic soil $\mathrm{C}$, total concentrations of free amino acids and DGT extractable $\mathrm{Zn}$ and $\mathrm{Cd}$ (Grüter et al. 2017a). Finally, the release of $\mathrm{Zn}$ and $\mathrm{Cd}$ from decomposing green manure could also explain some of the increase. However, in the pot experiment conducted by Aghili et al. (2014), only a small fraction of $\mathrm{Zn}$ taken up by wheat originated from decomposing green manure and the rest was derived from the resident soil Zn pool.

In the LOW Zn soil, irrespectively of the treatment, DGT extractable $\mathrm{Zn}$ and Cd values were generally close to zero at wheat flowering (Fig. 1B). Consequently, it is hard to appreciate the effects of our factors, especially on DGT extractable Zn, earlier measurements (e.g. at wheat tillering) would have probably shown larger differences between the treatments. The absence of correlations between DGT Zn measured in the LOW Zn soil at wheat flowering and the other soil parameters was due to the variability and low DGT Zn values observed in this soil. Higher 
uptake of $\mathrm{Zn}$ and $\mathrm{Cd}$ by the wheat plants in x-ray irradiated LOW Zn might explain why no increased DGT $\mathrm{Zn}$ and $\mathrm{Cd}$ were found in these treatments in response to green manure addition. It is also possible that $\mathrm{Zn}$ and $\mathrm{Cd}$ released after clover incorporation precipitated with carbonates, which were abundant in the LOW Zn soil (Table 1). Moreover, Zn concentration of the clover grown in the LOW $\mathrm{Zn}$ soil were close to critical values for plant growth (White 1993). This could decrease its $\mathrm{N}$ fixation capabilities explaining lower $\mathrm{N}$ and clover inputs in this soil, and thus less effects of the green manure incorporation on the availability of $\mathrm{Zn}$ and $\mathrm{Cd}$ in the LOW $\mathrm{Zn}$ than in the HIGH Zn soil.

Surprisingly, DGT extractable Cd levels were decreased by green manure incorporation in the x-ray irradiated LOW $\mathrm{Zn}$ treatments at wheat flowering (Fig. 1B). This was probably due to higher wheat root $\mathrm{Cd}$ uptake in the X-RAY IRR soils, as the wheat grown in these treatments may have benefited from $\mathrm{N}$ released by irradiated microbial biomass. This was supported by the fact that we found the highest $\mathrm{NH}_{4}{ }^{+}$ concentrations (Table 5), grain biomass (Table 7) and number of grains produced per kg soil ${ }^{-1}$ (Table S4) in the + GM_X-RAY IRR treatments.

The wheat plants did not benefit from the increased soil $\mathrm{Zn}$ availabilities

Higher $\mathrm{Zn}$ availabilities in the $+\mathrm{GM}$ treatments were not associated with more wheat biomass nor with higher wheat $\mathrm{Zn}$ uptake. In the LOW Zn soil, this was in spite of clear wheat $\mathrm{Zn}$ deficiency symptoms (chlorosis and necrotic spots on the leaves) and very low shoot and grain $\mathrm{Zn}$ concentrations (ca. 3 and $10 \mathrm{mg} \mathrm{Zn} \mathrm{kg}{ }^{-1}$, respectively), considered as critical for wheat growth (White 1993). Contrasting results were obtained in a recent pot experiment conducted by Grüter et al. (2017b) using the same two soils, as well as the same clover and wheat variety, but under different growing conditions (climate chamber with higher air temperature and a different lighting system). In their study, the incorporation of clover green manure increased aboveground wheat $\mathrm{Zn}$ uptake by almost a factor of two in the LOW $\mathrm{Zn}$ and of five in the HIGH $\mathrm{Zn}$ soil. These different results might partly be explained by the higher amounts of clover incorporated in the study of Grüter et al. (2017b) (9.57 $\mathrm{g}$ and $5.21 \mathrm{~g}$ clover shoots per $\mathrm{kg}$ of HIGH $\mathrm{Zn}$ and LOW Zn soil, respectively, in comparison to the amounts of 2.97 and $2.61 \mathrm{~g}$ in our experiment (see Table 3)). In this way, three to four times more $\mathrm{N}$ was incorporated with the clover shoots of Grüter et al. (2017b) leading to a strong increase in soil mineral $\mathrm{N}$ concentrations which was not the case in our experiment. Higher $\mathrm{N}$ input through green manure addition in that study might have increased the acquisition of Zn by the plant through the mechanisms mentioned above (i.e. higher root growth and soil exploitation, stimulation of root root-to-shoot transfer and remobilization of metals to the grain). In line with this and in agreement with several other studies (Cakmak et al. 2010; Kutman et al. 2010), we found positive correlations between wheat shoot and grains $\mathrm{N}$ and $\mathrm{Zn}$ and $\mathrm{Cd}$ concentrations (Table 7). Similarly as in Grüter et al. (2017b), we found more wheat root and shoot (excluding grains) biomass production in the LOW $\mathrm{Zn}$ soil than in the HIGH $\mathrm{Zn}$ soil, which may partly be atttributed to the poor soil structure of the HIGH Zn soil (observed by high soil density and distribution of the roots along the pot walls). Low aggregate stability was confirmed by a low $\mathrm{Ca}$ content (1.68 $\mathrm{g} \mathrm{kg}^{-1}$ ), which is known to improve aggregate stability through building $\mathrm{Ca}$ bonds between clay and humus particles (Blume et al. 2016). Less grain biomass production was nevertheless found in the LOW $\mathrm{Zn}$ soil, probably because of wheat $\mathrm{N}$ limitations in this soil (see below).

In order to study specifically the effect of fresh green manure input on bacterial activity and its ability to mobilize $\mathrm{Zn}$ and $\mathrm{Cd}$, we incorporated the clover shoot one week before the start of the wheat growth experiment. Even with a $\mathrm{C} / \mathrm{N}$ ratio below 20 , it generally takes a few weeks before mineral $\mathrm{N}$ gets released from decomposing green manure (Doran and Smith 1991; Green and Blackmer 1995). Thus, we found lower mineral N concentrations in the + GM compared to the NO GM treatments at wheat planting in both soils, which probably explains why wheat growth generally tended to be negatively affected by green manure incorporation (i.e. decreased aboveground biomass and lower number of grains produced per $\mathrm{kg}$ soil ${ }^{-1}$ ). This was more observed in the non-irradiated than in the irradiated treatments since, as mentioned above, the radiation might have contributed to the release of $\mathrm{N}$ immobilized by soil microbes in the presence of green manure. In the LOW $\mathrm{Zn}$ soil, 
this release of $\mathrm{N}$ might have slightly favored wheat growth as indicated by the highest grain biomass in the +GM_X-RAY IRR treatments (Table 7). Although in the HIGH Zn soil, microbial death and green manure $\mathrm{N}$ mineralization could bring the $\mathrm{NO}$ $\mathrm{GM}$ and the + GM treatments to similar wheat $\mathrm{N}$ concentrations, this was not the case in the LOW $\mathrm{Zn}$ soil where wheat treated with green manure still had lower shoot and grain $\mathrm{N}$ concentrations at wheat maturity (Fig. 4). Consequently, wheat N status was either not affected (in the HIGH $\mathrm{Zn}$ soil) or decreased (in the LOW $\mathrm{Zn}$ soil) by the incorporation of green manure. In the LOW Zn soil, no matter the treatment, $\mathrm{N}$ concentrations at wheat flowering in the shoots were either close or below critical values for wheat growth (ca. $21 \mathrm{mg} \mathrm{N} \mathrm{kg}^{-1}$, Fig S2) (Reuter and Robinson 1997). The incorporation of green manure therefore further exacerbated wheat $\mathrm{N}$ limitations in this soil, although this was mostly observed in the NO IRR treatments. The uptake of $\mathrm{N}$ by wheat may have also been limited by high soil moisture content, poor solar radiations on the glasshouse bench and the small pot sizes leading to high root density, which are all common phenomena in pot experiments (Meyer et al. 2017b; Passioura 2006).

Considering the importance of $\mathrm{N}$ in the processes leading to metal uptake and translocation within plants, it is likely that $\mathrm{N}$ limitations in the $+\mathrm{GM}$ treatments of the LOW $\mathrm{Zn}$ soil prevented the wheat plants to benefit from higher $\mathrm{Zn}$ availabilities. The other factors mentioned above may have additionally limited wheat plant growth and metal uptake in both soils. The very high shoot and grain $\mathrm{Zn}$ concentrations encountered in the HIGH Zn soil (ca. 30 and $60 \mathrm{mg} \mathrm{Zn} \mathrm{kg}^{-1}$, respectively) may have also prevented any further increase in wheat $\mathrm{Zn}$ uptake in the treatments where green manure had been incorporated. However, using the same soil and wheat variety, Grüter et al. (2017b) observed an increase in wheat grain $\mathrm{Zn}$ concentrations from ca. $60 \mathrm{mg} \mathrm{Zn}$ $\mathrm{kg}^{-1}$ in the control without green manure to $95 \mathrm{mg}$ $\mathrm{Zn} \mathrm{kg}$, when the same clover was incorporated. In the latter experiment, the incorporation of clover decreased soil $\mathrm{pH}$ by nearly one $\mathrm{pH}$ unit, which might have indirectly increased wheat $\mathrm{Zn}$ uptake due to increased $\mathrm{Zn}$ availability on their HIGH $\mathrm{Zn}$ soil. Finally, the fact that in the LOW Zn soil, the incorporation of green manure lowered wheat shoot and grain $\mathrm{Cd}$, but not $\mathrm{Zn}$ concentrations, suggests that the plants controlled the uptake of $\mathrm{Zn}$ homeostatically, for instance through the production of Zn specific phytosiderophores (Puschenreiter et al. 2017).

ZSB inoculation did not affect $\mathrm{Zn}$ and $\mathrm{Cd}$ availability to wheat

Two of the inoculated strains (S. narbonensis and $P$. moraviensis) were isolated from the HIGH $\mathrm{Zn}$ soil itself, and the four others from a soil with very similar chemical properties (Costerousse et al. 2018). Thus, the inoculated bacteria were most probably capable to grow in this soil, although we have no experimental data supporting this. For the inoculated strains, mechanisms of $\mathrm{Zn}$ solubilization are thought to include various metabolic processes, indirectly involved in the mobilization of $\mathrm{Zn}$ such as organic acid production (i.e. from the extracellular oxidation of glucose or from the tricarboxylic acid cycle) and proton extrusion for bacterial respiration and charge balance maintenance (Gadd 2004; Glasauer et al. 2004). In Costerousse et al. (2018), the magnitude of these metabolic processes was highly dependent on the availability of nutrients, since the mere presence/absence of glucose was sufficient to inhibit $\mathrm{Zn}$ oxide solubilization for most of the inoculated ZSB. It is likely that glucose availability in the HIGH $\mathrm{Zn}$ soil was inadequate for the bacteria to reiterate $\mathrm{Zn}$ mobilization mechanisms highlighted under in vitro conditions. Reasons explaining that there was no increase in $\mathrm{Zn}$ and $\mathrm{Cd}$ mobilization following the inoculation with ZSB might be soil specific. Differences in $\mathrm{pH}$, soil organic matter content and nutrient availabilities between ZSB's soils of origin and the LOW Zn soil are among the numerous factors which might have further negatively affected the survival of the inoculated strains and their capacities to solubilize $\mathrm{Zn}$ in this soil (Gyaneshwar et al. 2002; Mosimann et al. 2017).

\section{Conclusions}

In this experiment, no biofortification effects of green manure incorporation in soils with sufficient and nonsufficient $\mathrm{Zn}$ availability (respectively referred to as HIGH $\mathrm{Zn}$ and LOW Zn) were found. This happened 
despite the fact that clover incorporation increased soil $\mathrm{Zn}$ availability, but wheat $\mathrm{Zn}$ uptake might have been restricted by $\mathrm{N}$ limitations (in the LOW Zn soil), plant Zn homeostasis (in the HIGH Zn soil) and other factors inherent to pot experiments (e.g. high soil moisture content and root density in the pots). These findings therefore suggest the importance to provide crops with sufficient phytoavailable $\mathrm{N}$ so that it can benefit from higher $\mathrm{Zn}$ supply in soils where available $\mathrm{Zn}$ is too low to cover crop needs, be it through the addition of mineral or organic fertilizers. The results confirm that green manure incorporation can stimulate soil bacterial activity and that this increase is positively related to a mobilization of $\mathrm{Zn}$ in soil. We found no increasing effect of pure strains inoculation (i.e. ZSB consortium) on $\mathrm{Zn}$ availability in soil and its uptake by wheat. Thus, our study does not support the use of ZSB inoculum for increasing grain $\mathrm{Zn}$ concentrations. Instead, our results suggest that the native soil bacteria can mobilize soil $\mathrm{Zn}$ and that this may be enhanced via the incorporation of green manure, although it may not necessarily translate into higher wheat grain $\mathrm{Zn}$ concentrations due to the factors mentioned above.

Acknowledgements We thank Ismail Cakmak (Sabanci University, Istanbul) and Jochen Mayer (Agroscope, Zurich) for providing the soils, Rainer Schulin and Susan Tandy (Group of Soil Protection, Institute of Terrestrial Ecosystems, ETH Zurich) for fruitful discussions. We are grateful to Ekaterina Pushkareva for her help with the manuscript submission. We also acknowledge the Mercator Research Program of the ETH Zurich World Food System Center and the ETH Zurich Foundation for funding this project. The funders had no role in study design, data collection and interpretation, or the decision to submit the work for publication.

Funding Open Access funding provided by ETH Zurich.

\section{Declarations}

Not applicable.

Open Access This article is licensed under a Creative Commons Attribution 4.0 International License, which permits use, sharing, adaptation, distribution and reproduction in any medium or format, as long as you give appropriate credit to the original author(s) and the source, provide a link to the Creative Commons licence, and indicate if changes were made. The images or other third party material in this article are included in the article's Creative Commons licence, unless indicated otherwise in a credit line to the material. If material is not included in the article's Creative Commons licence and your intended use is not permitted by statutory regulation or exceeds the permitted use, you will need to obtain permission directly from the copyright holder. To view a copy of this licence, visit http://creativecommons.org/licenses/by/4.0/.

\section{References}

Abaid-Ullah M, Hassan MN, Jamil M, Brader G, Shah MKN, Sessitsch A, Hafeez FY (2015) Plant growth promoting rhizobacteria: an alternate way to improve yield and quality of wheat (Triticum aestivum). Int J Agric Biol 17:51-60

Aghili F, Gamper HA, Eikenberg J, Khoshgoftarmanesh AH, Afyuni M, Schulin R, Jansa J, Frossard E (2014) Green manure addition to soil increases grain zinc concentration in bread wheat. PLoS ONE 9:e101487. https://doi.org/10. 1371/journal.pone.0101487

Alloway BJ (2009) Soil factors associated with zinc deficiency in crops and humans. Environ Geochem Health 31:537548. https://doi.org/10.1007/s10653-009-9255-4

Bingeman CW, Varner J, Martin W (1953) The effect of the addition of organic materials on the decomposition of an organic soil. Soil Sci Soc Am J 17:34-38

Blume H-P, Brümmer GW, Fleige H, Horn R, Kandeler E, Kögel-Knabner I, Kretzschmar R, Stahr K, Wilke B-M (2016) Scheffer/Schachtschabel soil science. Springer, Berlin

Bobrov AG, Kirillina O, Fetherston JD, Miller MC, Burlison JA, Perry RD (2014) The Yersinia pestis siderophore, yersiniabactin, and the ZnuABC system both contribute to zinc acquisition and the development of lethal septicaemic plague in mice. Mol Microbiol 93:759-775. https://doi. org/10.1111/mmi.12693

Brandel J, Humbert N, Elhabiri M, Schalk IJ, Mislin GLA, Albrecht-Gary A-M (2012) Pyochelin, a siderophore of Pseudomonas aeruginosa: physicochemical characterization of the iron(III), copper(II) and zinc(II) complexes. Dalton Trans 41:2820-2834. https://doi.org/10.1039/ c1dt11804h

Broadley MR, White PJ, Hammond JP, Zelko I, Lux A (2007) Zinc in plants. New Phytol 173:677-702. https://doi.org/ 10.1111/j.1469-8137.2007.01996.x

Cakmak I (2008) Enrichment of cereal grains with zinc: agronomic or genetic biofortification? Plant Soil 302:1-17. https://doi.org/10.1007/s11104-007-9466-3

Cakmak I, Yilmaz A, Kalayci M, Ekiz H, Torun B, Erenoglu B, Braun HJ (1996) Zinc deficiency as a critical problem in wheat production in Central Anatolia. Plant Soil 180:165-172. https://doi.org/10.1007/bf00015299

Cakmak I, Pfeiffer WH, McClafferty B (2010) Biofortification of durum wheat with zinc and iron. Cereal Chem 87:1020. https://doi.org/10.3389/fpls.2014.00053

Costerousse B, Schönholzer-Mauclaire L, Frossard E, Thonar C (2018) Identification of heterotrophic Zinc mobilization processes among bacterial strains isolated from wheat rhizosphere (Triticum aestivum L.). Appl Environ Microbiol 84:e01715-01717. https://doi.org/10.1128/AEM. 01715-17

Doran JW, Smith MS (1991) Role of cover crops in nitrogen cycling. In: Hargroce LW (ed) Cover crops for clean water. SWCS, Ankeny, pp 85-90

Fasim F, Ahmed N, Parsons R, Gadd GM (2002) Solubilization of zinc salts by a bacterium isolated from the air environment of a tannery. FEMS Microbiol Lett 213:1-6. https:// doi.org/10.1111/j.1574-6968.2002.tb11277.x 
Fomina MA, Alexander IJ, Colpaert JV, Gadd GM (2005) Solubilization of toxic metal minerals and metal tolerance of mycorrhizal fungi. Soil Biol Biochem 37:851-866. https:// doi.org/10.1016/j.soilbio.2004.10.013

Frossard E, Bucher M, Machler F, Mozafar A, Hurrell R (2000) Potential for increasing the content and bioavailability of $\mathrm{Fe}, \mathrm{Zn}$ and $\mathrm{Ca}$ in plants for human nutrition. J Sci Food Agric 80:861-879. https://doi.org/10.1002/(sici)10970010(20000515)80:7\%3c861::aid-jsfa601\%3e3.3.co;2-g

Gadd GM (2004) Microbial influence on metal mobility and application for bioremediation. Geoderma 122:109-119. https://doi.org/10.1016/j.goederma.2004.01.002

Glasauer S, Beveridge T, Burford E, Harper F, Gadd G (2004) Metals and metalloids, transformation by microorganisms. In: Hillel D, Rosenzweig C, Powlson DS, Scow KM, Singer MJ, Sparks DL, Hatfield J (eds) Encyclopedia of soils in the environment. Elsevier, Amsterdam, pp 438-447

Godt J, Scheidig F, Grosse-Siestrup C, Esche V, Brandenburg P, Reich A, Groneberg DA (2006) The toxicity of cadmium and resulting hazards for human health. J Occup Med Toxicol 1:22. https://doi.org/10.1186/ 1745-6673-1-22

Graham RD, Welch RM (1996) Breeding for staple food crops with high micronutrient density: working papers on agricultural strategies for micronutrients, No.3. International Food Policy Institute, Washington DC

Gramlich A, Tandy S, Frossard E, Eikenberg J, Schulin R (2013) Availability of zinc and the ligands citrate and histidine to wheat: does uptake of entire complexes play a role? J Agric Food Chem 61:10409-10417. https://doi. org/10.1021/jf401117d

Green C, Blackmer A (1995) Residue decomposition effects on nitrogen availability to corn following corn or soybean. Soil Sci Soc Am J 59:1065-1070

Grüter R, Costerousse B, Bertoni A, Mayer J, Thonar C, Frossard E, Schulin R, Tandy S (2017a) Green manure and long-term fertilization effects on soil zinc and cadmium availability and uptake by wheat (Triticum aestivum L.) at different growth stages. Sci Total Environ 599:1330-1343. https://doi.org/10.1016/j.scitotenv. 2017.05.070

Grüter R, Meister A, Schulin R, Tandy S (2017b) Green manure effects on zinc and cadmium accumulation in wheat grains (Triticum aestivum L.) on high and low zinc soils. Plant Soil 1-17. https://doi.org/10.1007/ s11104-017-3486-4

Gyaneshwar P, Kumar GN, Parekh LJ, Poole PS (2002) Role of soil microorganisms in improving $\mathrm{P}$ nutrition of plants. Plant Soil 245:83-93. https://doi.org/10.1023/a: 1020663916259

Habiby H, Afyuni M, Khoshgoftarmanesh AH, Schulin R (2014) Effect of preceding crops and their residues on availability of zinc in a calcareous $\mathrm{Zn}$-deficient soil. Biol Fertil Soils 50:1061-1067. https://doi.org/10.1007/ s00374-014-0926-7

Hafeez FY, Abaid-Ullah M, Hassan MN (2013) Plant growthpromoting rhizobacteria as zinc mobilizers: a promising approach for cereals biofortification. In: Maheshwari DK, Saraf M, Aeron A (eds) Bacteria in agrobiology: crop productivity. Springer, Berlin, pp 217-235
Hart JJ, Welch RM, Norvell WA, Kochian LV (2002) Transport interactions between cadmium and zinc in roots of bread and durum wheat seedlings. Physiol Plant 116:7378. https://doi.org/10.1034/j.1399-3054.2002.1160109.x

Holt RR, Uriu-Adams JY, Keen CL (2012) Zinc. In: Erdman JW, Macdonald IA, Zeisel SH (eds) Present knowledge in nutrition, 10th edn. Wiley, Oxford, pp 521-539

IUSS Working Group WRB (2014) World reference base for soil resources. International soil classification system for naming soils and creating legends for soil maps. World Soil Resources Reports No. 106. FAO, Rome

Jansa J, Mozafar A, Frossard E (2003) Long-distance transport of $\mathrm{P}$ and $\mathrm{Zn}$ through the hyphae of an arbuscular mycorrhizal fungus in symbiosis with maize. Agronomie 23:481-488. https://doi.org/10.1051/agro:2003013

Javed H, Naeem A, Rengel Z, Dahlawi S (2016) Timing of foliar $\mathrm{Zn}$ application plays a vital role in minimizing Cd accumulation in wheat. Environ Sci Pollut Res Int 23:16432-16439. https://doi.org/10.1007/ s11356-016-6822-y

Jenkinson DS, Brookes PC, Powlson DS (2004) Measuring soil microbial biomass. Soil Biol Biochem 1:5-7. https://doi. org/10.1016/j.soilbio.2003.10.002

Khande R, Sharma SK, Ramesh A, Sharma MP (2017) Zinc solubilizing Bacillus cereus and related species modulates growth, yield and zinc biofortification of soybean and wheat seeds cultivated in central India. Rhizosphere 4:126-138. https://doi.org/10.1016/j.rhisph.2017.09.002

Khoshgoftar A, Shariatmadari H, Karimian N, Kalbasi M, Van der Zee S, Parker D (2004) Salinity and zinc application effects on phytoavailability of cadmium and zinc. Soil Sci Soc Am J 68:1885-1889. https://doi.org/10.2136/sssaj 2004.1885

Kothari SK, Marschner H, Romheld V (1991) Contribution of the VA mycorrhizal hyphae in acquisition of phosphorus and zinc by maize grown in a calcareous soil. Plant Soil 131:177-185. https://doi.org/10.1007/BF00009447

Kutman UB, Yildiz B, Ozturk L, Cakmak I (2010) Biofortification of durum wheat with zinc through soil and foliar applications of nitrogen. Cereal Chem 87:1-9. https://doi. org/10.1094/cchem-87-1-0001

Leach LH, Morris JC, Lewis TA (2007) The role of the siderophore pyridine-2, 6-bis (thiocarboxylic acid) (PDTC) in zinc utilization by Pseudomonas putida DSM 3601. Biometals 20:717. https://doi.org/10.1007/s10534-006-9035-x

Lensi R, Lescure C, Steinberg C, Savoie J-M, Faurie G (1991) Dynamics of residual enzyme activities, denitrification potential, and physico-chemical properties in a $\gamma$-sterilized soil. Soil Biol Biochem 23:367-373. https://doi.org/10. 1016/0038-0717(91)90193-N

Li WC, Ye ZH, Wong MH (2010) Metal mobilization and production of short-chain organic acids by rhizosphere bacteria associated with a $\mathrm{Cd} / \mathrm{Zn}$ hyperaccumulating plant, Sedum alfredii. Plant Soil 326:453-467. https://doi.org/ 10.1007/s11104-009-0025-y

Marschner B, Bredow A (2002) Temperature effects on release and ecologically relevant properties of dissolved organic carbon in sterilised and biologically active soil samples. Soil Biol Biochem 34:459-466. https://doi.org/10.1016/ S0038-0717(01)00203-6 
Martino E, Perotto S, Parsons R, Gadd GM (2003) Solubilization of insoluble inorganic zinc co mpounds by ericoid mycorrhizal fungi derived from heavy metal polluted sites. Soil Biol Biochem 35:133-141. https://doi.org/10. 1016/s0038-0717(02)00247-x

McNamara N, Black H, Beresford N, Parekh N (2003) Effects of acute gamma irradiation on chemical, physical and biological properties of soils. Appl Soil Ecol 24:117-132. https://doi.org/10.1016/S0929-1393(03)00073-8

Meyer G, Bünemann EK, Frossard E, Maurhofer M, Mäder P, Oberson A (2017a) Gross phosphorus fluxes in a calcareous soil inoculated with Pseudomonas protegens CHA0 revealed by $33 \mathrm{P}$ isotopic dilution. Soil Biol Biochem 104:81-94. https://doi.org/10.1016/j.soilbio.2016.10.001

Meyer G, Frossard E, Mäder P, Nanzer S, Randall D, Udert K, Oberson A (2017b) Water soluble phosphate fertilizers for crops grown in calcareous soils-an outdated paradigm for recycled phosphorus fertilizers? Plant Soil 1-22.https:// doi.org/10.1007/s11104-017-3545-x

Mosimann C, Oberhänsli T, Ziegler D, Nassal D, Kandeler E, Boller T, Mäder P, Thonar C (2017) Tracing of two Pseudomonas strains in the root and rhizoplane of maize, as related to their plant growth-promoting effect in contrasting soils. Front Microbiol 7:2150. https://doi.org/10.3389/ fmicb.2016.02150

Muehe EM, Weigold P, Adaktylou IJ, Planer-Friedrich B, Kraemer U, Kappler A, Behrens S (2015) Rhizosphere microbial community composition affects cadmium and zinc uptake by the metal-hyperaccumulating plant Arabidopsis halleri. Appl Environ Microbiol 81:2173-2181. https://doi.org/10.1128/AEM.03359-14

Nan Z, Li J, Zhang J, Cheng G (2002) Cadmium and zinc interactions and their transfer in soil-crop system under actual field conditions. Sci Total Environ 285:187-195. https:// doi.org/10.1016/S0048-9697(01)00919-6

Nolan AL, Lombi E, McLaughlin MJ (2003) Metal bioaccumulation and toxicity in soils - Why bother with speciation? Aust J Chem 56:77-91. https://doi.org/10.1071/ch02226

Nouri E, Breuillin-Sessoms F, Feller U, Reinhardt D (2014) Phosphorus and nitrogen regulate arbuscular mycorrhizal symbiosis in Petunia hybrida. PLoS ONE 9:e90841. https://doi.org/10.1371/journal.pone.0090841

Oberholzer HR, Leifeld J, Mayer J (2014) Changes in soil carbon and crop yield over 60 years in the Zurich Organic Fertilization Experiment, following land-use change from grassland to cropland. J Plant Nutr Soil Sci 177:696-704. https://doi.org/10.1002/jpln.201300385

Oliver DP, Hannam R, Tiller K, Wilhelm N, Merry RH, Cozens G (1994) The effects of zinc fertilization on cadmium concentration in wheat grain. J Environ Qual 23:705711. https://doi.org/10.2134/jeq1994.004724250023000 $40013 \mathrm{x}$

Ortas I (2012) Do maize and pepper plants depend on mycorrhizae in terms of phosphorus and zinc uptake? J Plant Nutr 35:1639-1656. https://doi.org/10.1080/01904167. 2012.698346

Palmer CM, Guerinot ML (2009) Facing the challenges of $\mathrm{Cu}$, $\mathrm{Fe}$ and $\mathrm{Zn}$ homeostasis in plants. Nat Chem Biol 5:333340. https://doi.org/10.1038/nchembio.166

Passioura JB (2006) The perils of pot experiments. Funct Plant Biol 33:1075-1079. https://doi.org/10.1071/FP06223
Phillips JM, Hayman D (1970) Improved procedures for clearing roots and staining parasitic and vesicular-arbuscular mycorrhizal fungi for rapid assessment of infection. Trans Br Mycol Soc 55:158-161. https://doi.org/10.1016/ S0007-1536(70)80110-3

Puschenreiter M, Gruber B, Wenzel WW, Schindlegger Y, Hann S, Spangl B, Schenkeveld WD, Kraemer SM, Oburger E (2017) Phytosiderophore-induced mobilization and uptake of $\mathrm{Cd}, \mathrm{Cu}, \mathrm{Fe}, \mathrm{Ni}, \mathrm{Pb}$ and $\mathrm{Zn}$ by wheat plants grown on metal-enriched soils. Environ Exp Bot 138:6776. https://doi.org/10.1016/j.envexpbot.2017.03.011

Reuter D, Robinson JB (1997) Plant analysis: an interpretation manual. CSIRO publishing, Collingwood

Salonius P, Robinson J, Chase F (1967) A comparison of autoclaved and gamma-irradiated soils as media for microbial colonization experiments. Plant Soil 27:239-248. https:// doi.org/10.1007/BF01373392

Saravanan VS, Madhaiyan M, Thangaraju M (2007) Solubilization of zinc compounds by the diazotrophic, plant growth promoting bacterium Gluconacetobacter diazotrophicus. Chemosphere 66:1794-1798. https://doi.org/ 10.1016/j.chemosphere.2006.07.067

Sarwar N, Bibi S, Ahmad M, Ok YS (2014) Effectiveness of zinc application to minimize cadmium toxicity and accumulation in wheat (Triticum aestivum L.). Environ Earth Sci 71:1663-1672. https://doi.org/10.1007/ s12665-013-2570-1

Sarwar N, Ishaq W, Farid G, Shaheen MR, Imran M, Geng M, Hussain S (2015) Zinc-cadmium interactions: impact on wheat physiology and mineral acquisition. Ecotoxicol Environ Saf 122:528-536. https://doi.org/10.1016/j. ecoenv.2015.09.011

Sharma SK, Sharma MP, Ramesh A, Joshi OP (2012) Characterization of zinc-solubilizing Bacillus isolates and their potential to influence zinc assimilation in soybean seeds. J Microbiol Biotechnol 22:352-359. https://doi.org/10. 4014/jmb.1106.05063

Siddique S, Hamid M, Tariq A, Kazi AG (2014) Organic farming: the return to nature. In: Ahmad P, Wani M, Azooz M, Phan Tran LS (eds) Improvement of crops in the era of climatic changes. Springer, New York, pp 249-281

Singh D, Rajawat MVS, Kaushik R, Prasanna R, Saxena AK (2017) Beneficial role of endophytes in biofortification of $\mathrm{Zn}$ in wheat genotypes varying in nutrient use efficiency grown in soils sufficient and deficient in $\mathrm{Zn}$. Plant Soil 1-10.https://doi.org/10.1007/s11104-017-3189-x

Soltani S, Khoshgoftarmanesh AH, Afyuni M, Shrivani M, Schulin R (2014) The effect of preceding crop on wheat grain zinc concentration and its relationship to total amino acids and dissolved organic carbon in rhizosphere soil solution. Biol Fertil Soils 50:239-247. https://doi.org/10. 1007/s00374-013-0851-1

Sunithakumari K, Devi SNP, Vasandha S (2016) Zinc solubilizing bacterial isolates from the agricultural fields of Coimbatore, Tamil Nadu, India. Curr Sci 110:196-205. https://doi.org/10.18520/cs/v110/i2/196-205

Tandy S, Mundus S, Yngvesson J, de Bang TC, Lombi E, Schjørring JK, Husted S (2011) The use of DGT for prediction of plant available copper, zinc and phosphorus in agricultural soils. Plant Soil 346:167-180. https://doi.org/ 10.1007/s11104-011-0806-y 
Thompson J (1990) Treatments to eliminate root-lesion nematode (Pratylenchus Thornei Sher \& Allen) from a vertisol. Nematologica 36:123-127. https://doi.org/10.1139/ g06-090

Trevors J (1996) Sterilization and inhibition of microbial activity in soil. J Microbiol Methods 26:53-59. https://doi.org/ 10.1016/0167-7012(96)00843-3

Watts-Williams SJ, Patti AF, Cavagnaro TR (2013) Arbuscular mycorrhizas are beneficial under both deficient and toxic soil zinc conditions. Plant Soil 371:299-312. https://doi. org/10.1007/s11104-013-1670-8

White C (1993) The zinc requirements of grazing ruminants. In: Robson AD (ed) Developments in plant and soil sciences. Springer, Dordrecht, pp 197-197
Wiggenhauser $\mathbf{M}$, Bigalke $\mathbf{M}$, Imseng $\mathbf{M}$, Müller M, Keller A, Murphy K, Kreissig K, Rehkamper M, Wilcke W, Frossard E (2016) Cadmium Isotope Fractionation in Soil-Wheat Systems. Environ Sci Technol 50:9223-9231. https://doi.org/10.1021/acs.est.6b01568

Publisher's note Springer Nature remains neutral with regard to jurisdictional claims in published maps and institutional affiliations. 